SOUTH EAST EUROPE

Transnational Cooperation Programme
SNA P P S S E E

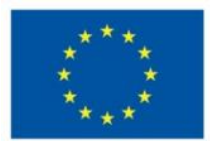

Programme co-funded by the EUROPEAN UNION

Consulting Stakeholders when Applying Best Practices in Sustainable Aggregates Planning

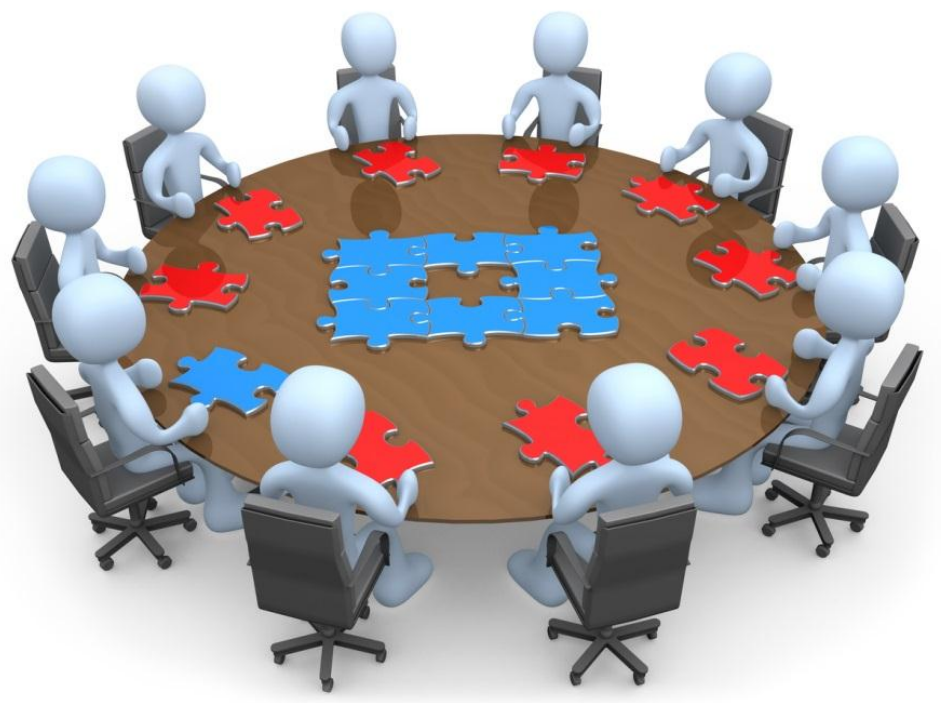

June 2014

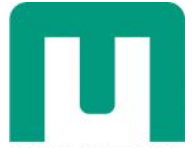

MONTAN UNIVERSITÄT

WWW.UNILEOBEN.AC.AT

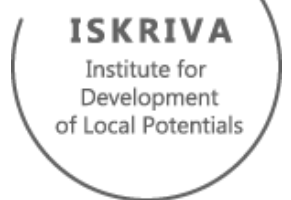

Institute for

Development Lotentials 



\section{Consulting Stakeholders when Applying Best Practices in Sustainable Aggregates Planning}

\section{Based on:}

the work and experience of project partners within Work Package 3 of the SNAP-SEE Project "Sustainable Aggregates Planning in South East Europe" (SEE/D/0167/2.4/X)

Website: http://www.snapsee.eu

Deliverable of Activity 3.3: Supporting materials for stakeholder consultations: Handbook on capacity building and stakeholder consultations in aggregates planning

\section{Publication Information}

Editing \& Layout: $\quad$ Foteini Stathogianni, Urška Dolinar

Cover Design: Stelios Mavrigiannakis

Printing: Geological Survey of Slovenia

Year of Edition: $\quad 2014$

\section{Disclaimer}

This SNAP-SEE publication reflects only the views of the authors and the Managing Authority of the South East Europe Transnational Cooperation Programme is not liable for any use that may be made of the information contained therein. CSNAP-SEE project 2014 
Dolinar, Urška, MBA, Iskriva, Institute for Development of Local Potentials, Slovenia Softić, Mateja, Iskriva, Institute for Development of Local Potentials, Slovenia Kozinc, Zdravko, Iskriva, Institute for Development of Local Potentials, Slovenia

\section{Contractor}

Montanuniversität Leoben (University of Leoben), Austria

\section{Reviewers}

\begin{tabular}{ll}
\hline Name & Affiliation \\
\hline Shields, Deborah J., Dr. & Montanuniversität Leoben (University of Leoben), Austria \\
O'Brien, Jim & Former President of the European Aggregates Association, Ireland
\end{tabular}

\section{Acknowledgment}

The SNAP-SEE project partners would like to thank the European Commission for funding this project which led to a fruitful cooperation between partners sharing similar issues and a common vision, and allowed the development of this handbook.

The authors would like to acknowledge the contribution of all partners in the development of the material presented in this handbook.

\section{Digital Object Identifier (DOI)}

10.5474/snapsee-WP3-EN

\section{Citation}

This handbook should be cited in the bibliography with using doi number as follows: Dolinar U., Softic M. and Z. Kozinc (2014), Handbook on Consulting Stakeholders when Applying Best Practices in Sustainable Aggregates Planning, SNAP-SEE, 2014. doi:10.5474/snapsee-WP3-EN 


\section{Consulting Stakeholders when Applying Best Practices in Sustainable Aggregates Planning}

CONTENTS Page

Foreword

1 Introductory Information

1.1 Scope of the Handbook

1.2 Structure of the Handbook 9

1.3 Aggregates Planning as Part of the Policy Cycle 10

$2 \quad$ Basic Principles of Stakeholder Involvement $\quad 11$

2.1 Reasons for Participation $\quad 12$

2.2 Benefits of Well Run Participation 13

2.3 Ways of Involving Stakeholders 14

$3 \quad$ Planning the Participatory Process $\quad 17$

$\begin{array}{lll}3.1 & \text { Before We Start } & 18\end{array}$

3.2 Steps for Planning the Participatory Process 19

3.3 Purpose of the Participatory Process and Steps in the Process 20

3.4 Timeline for Defining the Participatory Process 23

4 Who are the Stakeholders and How to Involve Them 25

4.1 Identification of Stakeholders in Aggregates Planning 26

4.2 Grouping the Stakeholders by Roles 27

$5 \quad$ Planning an Event with Stakeholders 32

5.1 Timeline for Organisation of an Event 33

5.2 Who is on My Team 34

5.3 Choosing the Right Time and Place for the Event 35

$5.4 \quad$ Event Purpose 36

5.5 How to Structure the Event 37

5.5.1 General Presentations 37

5.5.2 Capacity Building Presentations 37

5.5.3 Moderated Discussion 38

5.5.4 Workshop with Active Involvement of Participants 39

5.6 Preparing the Agenda and Invitations $\quad 41$

5.6.1 Event Agenda $\quad 41$ 
5.6.2 Invitations 43

$\begin{array}{lll}5.7 & \text { Detailed Plan of the Event } & 44\end{array}$

$6 \quad$ Techniques for Interactive Workshops $\quad 46$

$\begin{array}{lll}6.1 & \text { Before We Start } & 47\end{array}$

6.2 Dividing People into Groups 47

6.3 Carousel Brainstorming 48

$6.4 \quad$ World Café $\quad 50$

$7 \quad$ Implementing the Event $\quad 51$

7.1 Reviewing the Event and Briefing the Team 52

7.2 Setting up the Room 52

7.3 During the Event 53

7.4 Facilitation and Facilitators 53

$7.5 \quad$ Finishing the Event 54

$8 \quad$ After the Event - Follow-up $\quad 55$

$9 \quad$ Conclusions and Recommendations $\quad 57$

$\begin{array}{lll}10 & \text { References and Further Reading } & 62\end{array}$ 


\section{Foreword}

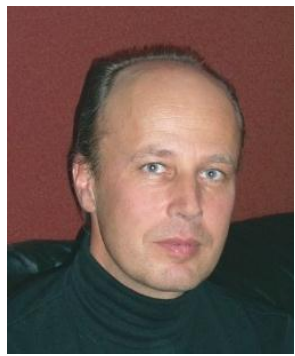

The countries in South East Europe (SEE) are rich in construction aggregates, i.e. crushed stone, gravel, sand and other granular inert materials used in the construction industry; however, these resources are not evenly distributed across the region resulting in abundance in some areas and shortage in others. Furthermore, access to these resources is becoming increasingly difficult due to other infrastructural developments and environmental pressures. As aggregates are heavy and bulky, transport is expensive, therefore access to resources local to the market is crucial. The SEE region will probably require $50 \%$ higher output of aggregates by 2020 in order to build its growing infrastructural needs.

Hence, there is a need to shift to sustainable aggregate resource management (SARM) and provide a sustainable supply mix (SSM) of aggregates to the region to enhance resource efficiency and support sustainable development. SARM is efficient, low socio-environmental impact quarrying and waste management, coupled with broad stakeholder engagement. A SSM is composed of aggregates from multiple sources, including recycled construction and demolition wastes and industrial byproducts (slag), as well as both domestically produced and imported primary materials, that together maximize net benefits of aggregate supply across generations.

Implementing SARM and SSM requires a supporting policy and planning framework. Due to regional differences and historical development, approaches to aggregates policy, planning and management differ at various political scales within and across SEE and in few cases are fully comprehensive. Challenges include policies and plans affecting aggregates management and provision that are distributed among many different legal documents, making coordination and a comprehensive understanding difficult. There is also a lack of coordination on planning for supply from primary and secondary aggregates. SEE lacks sufficient data to support aggregates planning, inadequate capacity and competence for addressing either primary and/or secondary aggregates planning, and insufficient stakeholder participation in the development of aggregates management plans. The SNAP-SEE Project has addressed these deficits in order to foster the growth of a vibrant, responsible and sustainable aggregates industry in the SEE region.

The specific purpose of the Sustainable Aggregates Planning in South East Europe (SNAP-SEE) project was to create and disseminate a Toolbox for Aggregates Planning to help governments and stakeholders in SEE collaborate to enhance their aggregates planning and management processes. SNAP-SEE built on the results of the Sustainable Aggregates Resource Management (SARMa) project, a preceding SEE Transna- 
tional Cooperation-funded project (http://www.sarma.eu). SNAP-SEE was funded by the EU South East Europe (SEE) Transnational Cooperation Programme (SNAP-SEE, SEE/D/0167/2.4/X) and had 27 partners from 12 SEE countries and Turkey. The University of Leoben, Austria, was the Lead Partner. SNAP-SEE was a 2 year project that ended in November of 2014.

The SNAP-SEE Toolbox for Aggregates Planning comprises 4 products that are interrelated and mutually supporting.

\section{A Vision of Best Practices for Aggregates Planning in South East Europe}

The 'Best Practices' document presents a Vision for a transition to integrated, comprehensive sustainable planning in SEE. It includes discussions of the issues that need to be addressed, interim steps that can be taken toward more sustainable planning, and a review of the components a sustainable plan should contain.

2. How to Build a Sustainable Aggregates Plan

The 'How to' document represents a roadmap for planning, including discussions of the planning process itself and its various steps. Examples of well written planning modules are provided that embody the principles, approaches and actions necessary to achieve the goals of the Vision laid out in the Best Practices report.

3. Consulting Stakeholders when Applying Best Practices in Sustainable Aggregates Planning

The 'Consultation' document provides a step-by-step guide for how to plan and conduct stakeholder consultations so as to ensure that industry, government, non-governmental organizations and civil society can provide input to and participate in the planning process. Capacity building materials are also provided.

4. Data and Analysis in Support of Best Practices in Sustainable Aggregates Planning

This document discusses the various types of data that provide essential background information for the planning process. Data definitions, significance, availability, structure and needs are addressed. Methods for validating and analyzing data are presented, including approaches to demand forecasting.

Project Coordinator

Guenter Tiess

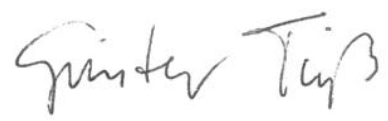

Montanuniversität Leoben

(University of Leoben) 


\section{Introductory Information}

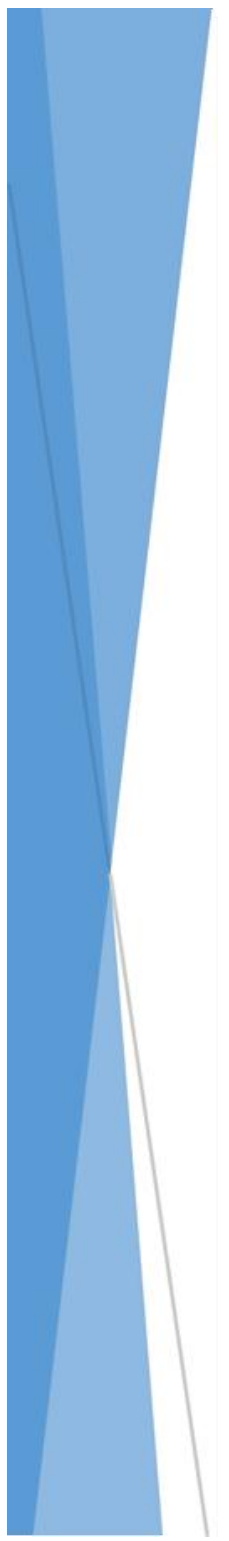

Planning aggregates supply is a responsibility of the national, regional and/or local governments as part of the minerals planning, mining and environmental policies. In order to assure efficient planning it is crucial to consult with a range of target groups that are involved in or affected by the aggregates policy and industry, i.e. the stakeholders, including governmental agencies and services at all levels, industry representatives, academia and experts, and nongovernmental organisations and civil society.

When involving stakeholders into decision-making processes, different approaches are possible, from informing to shared decision-making. The selection of the approach depends on the aims of the process and process holder.

This handbook provides insight into the consultations with stakeholders as a supporting activity when best practices in aggregates planning are being implemented at the national, regional or local level. It shows benefits of a participatory approach and provides practical advice on how to define the aims of stakeholder involvement and practically plan and implement the consultation events. 


\subsection{Scope of the Handbook}

Aggregates planning refers to a range of public policies intended to assure secure supply of aggregates needed for everything that is built in a country or region, from buildings to infrastructure. Primary aggregates are mainly sand, gravel, crushed stone; secondary aggregates can be recycled construction and demolition waste, manufactured aggregates, excavated materials from civil works etc.

Aggregates planning policies are declared governmental objectives in the field of aggregates; planning is the creation of formal procedures to be followed to achieve objectives; and management is the administration of plans. The project SNAP-SEE Sustainable Aggregates Planning in South East Europe (SEE) addressed a key question: how can SEE countries and regions improve their aggregates planning processes, integrate planning for primary and secondary aggregates to increase resource efficiency, and raise capacity levels among authorities, industry and civil society with respect to aggregates management, planning and supply.

Therefore, one of key aims is to increase capacity of planning authorities to become aware of these issues, and to enhance involvement of stakeholders in planning and implementation processes. Stakeholders are "people or organisations that will be affected by, or will influence a programme, project or action" (EC Guidance, 2010). Consequently, stakeholder involvement can include a range of different activities by different bodies and involving different groups or individuals, from information giving or collecting opinions to joint decision-making.

The purpose of this handbook is to provide practical advice in:

$\checkmark$ how to increase capacity of target groups related to aggregates planning;

$\checkmark$ how to identify different groups of stakeholders and suitable techniques for involving them;

$\checkmark$ how to plan a consultation process;

$\checkmark$ how to implement a consultation process and events; and

$\checkmark$ which methods and techniques can be used in consultations and capacity buildings.

Detailed guidance on aggregates planning is available in the first product of the Toolbox for Aggregates Planning, A Vision of Best Practices for Aggregates Planning in South East Europe. It provides general information on mineral planning and documents and presents the content of the planning documents and methods. 
Primary target group of this handbook are politicians and officials of national, regional and local authorities/governments and bodies from all sectors connected to aggregates planning, including mining and quarrying, construction, economy, environment, waste management, land use planning, water, transport etc.

Secondary target groups are all stakeholders involved in or affected by aggregates planning and management activities, from experts, representatives of the industry to local communities and non-governmental organisations (NGOs).

\subsection{Structure of the Handbook}

The handbook represents a mix of theoretical background and practical advice based on experience of the SNAP-SEE project. Chapter 2 explains key benefits and principles of participation and engagement of different target groups in planning. Chapters 3-8 are very practically oriented and offer advice when someone faces a challenge of organising a consultation process consisting of a range of different activities and events. Different tips are included and template tables are shown for planning an event. Generic templates are available for download at http://snapsee.eu/. The aim of the guidelines and the templates is to guide you through the process of planning participation and help you consider different aspects that have to be taken into account. Recommendations are summarized in chapter 9. Figure 1.1 shows the structure of the handbook, i.e. the main steps in planning the involvement of stakeholders.

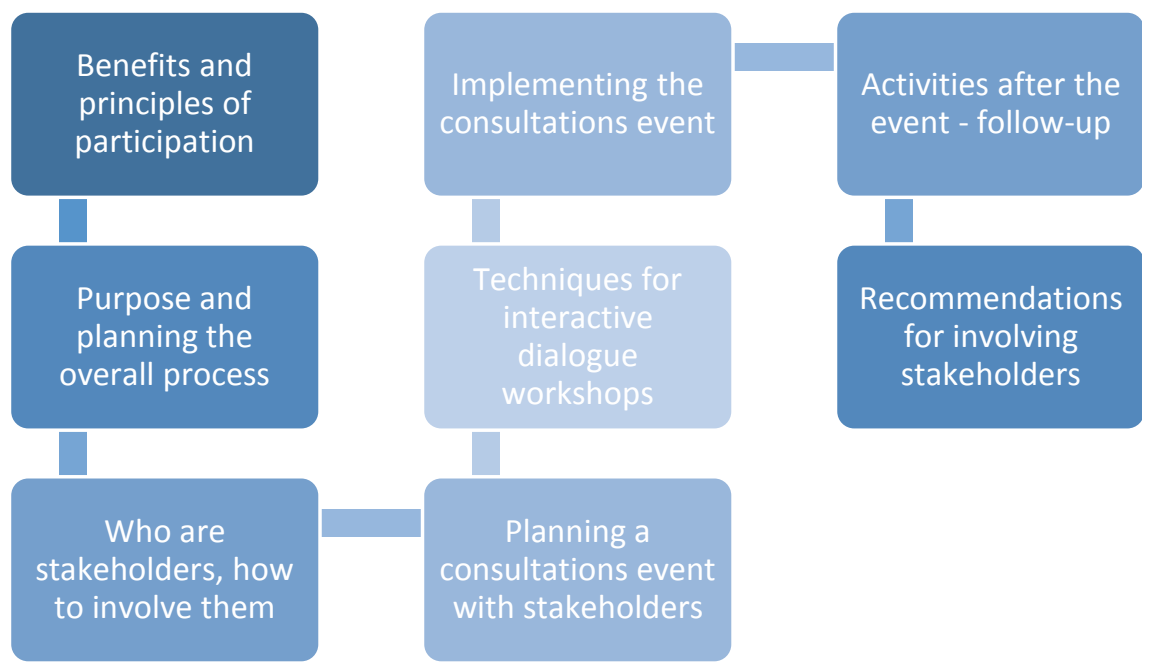

Figure 1.1: Key steps in planning the involvement of stakeholders 


\subsection{Aggregates Planning as Part of the Policy Cycle}

Each public policy is created to answer the needs from a certain field. The aggregates planning policy is replying to the needs of society for construction minerals. The aggregates planning policy is following the stages of the public policy cycle as shown in Figure 1.2. The aim of improving the policy in general can be divided into several stages - from identifying the current situation, to analysing good practices and bottlenecks, resulting in suggesting recommendations for improvements, creating an action plan to putting these improvements in practice, and monitoring results.

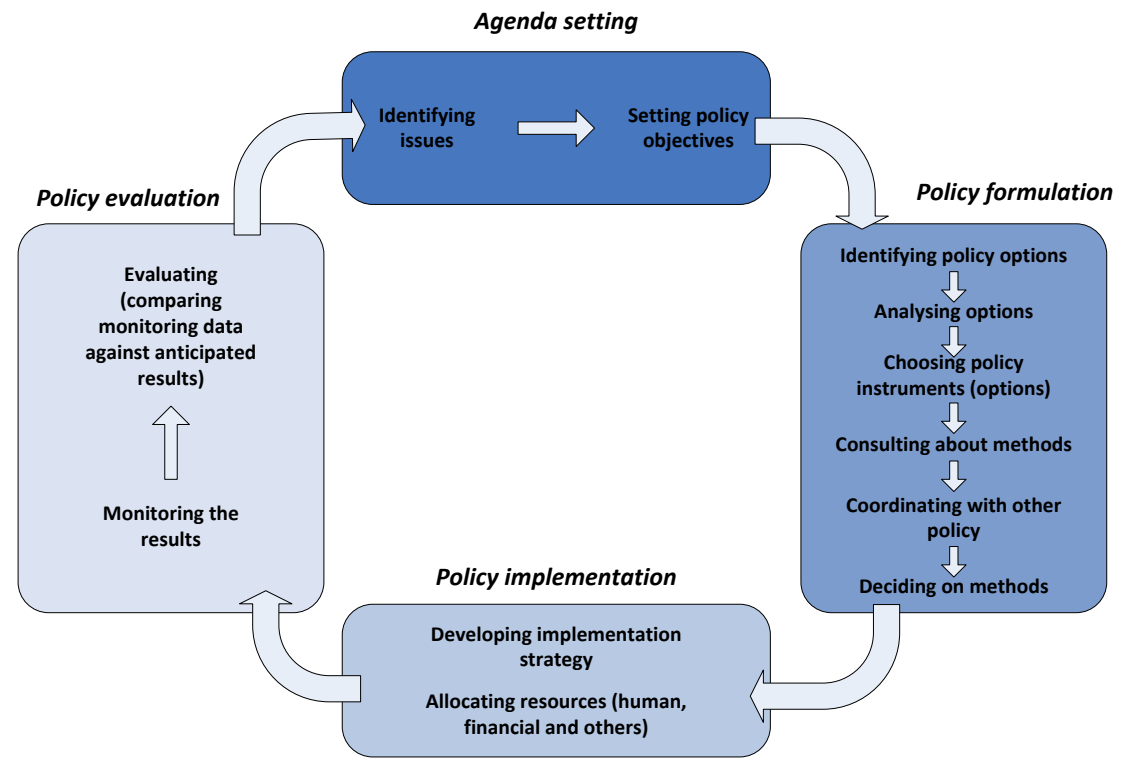

Figure 1.2: Public policy cycle

(http://www.mfe.govt.nz/publications/rma/drafting-issues-jul03/html/page2.html)

To be more specific, aggregates planning policy is part of the national (and/or regional) minerals policy. Minerals policy can be published as one guiding document (e.g. Austrian Minerals Plan), but more often it is considered in several documents in various fields under a responsibility of a national and/or regional government (mining and quarrying legislation and procedures, environment, waste management, water management etc.), meaning that there is no coherent approach. Consultations with stakeholders can be conducted in any phase of the policy cycle, aiming at evaluating the current situation and suggesting solutions and improvements. The consultations have to be adapted to the stage in policy cycle and their purpose has to be clearly defined. It is strongly recommended to start the consultations with stakeholders in as early stage as possible. 


\section{Basic Principles of Stakeholder Involvement}

Compared to the traditional public consultation approach when the decision is taken by a small group of people and later explained to the public, an integrative participatory approach has several benefits. It results in well informed decisions that are more easily implemented. Real problems are addressed and ownership of solutions is guaranteed by all involved parties. After all, costs are reduced and lasting change can be expected.

This chapter presents the difference between the traditional public consultation and the participatory approach of involving the stakeholders. Besides the benefits, it also explains different ways of involving stakeholders and key principles of their involvement.

Consultations implemented in the SNAP-SEE project have shown a number of benefits of involving different stakeholders in the planning process in a participatory manner: different opinions were shared, better solutions were identified, and cooperation among a number of institutions was enhanced. 


\subsection{Reasons for Participation}

When matters important for the public are being discussed, such as those affecting the next 20 years of aggregates planning and construction and several related industries, usually everyone agrees that public should be included in the discussion. However, there is a vast difference between traditional public consultation and stakeholder dialogue.

Traditional public consultation: typically a small group of people decide what should happen and then inform those affected. A lot of time is spent for explaining and justifying the decision. Wider stakeholders have limited opportunity to influence what is planned and are usually only consulted when most of the decisions have been made and written down. Implementation can be very difficult, especially if some interests or sectors feel their views have not been taken into account (Pound, 2008). The process takes longer and has smaller possibilities for good outcome.

Stakeholder involvement (terms also used in the text as synonyms: stakeholder dialogue/engagement/collaborative approach/public participation): the alternative is to take a collaborative approach from the start. This means engaging the stakeholders at an early stage when options are open and they can influence the outcome. Everyone shares knowledge and insights. Possible actions and ideas are explored before decisions are finalised and written. Using the knowledge, views and ideas of a wider group builds social capital, enriches the discussion and leads to better outcome (Pound, 2008). More time is spent for good preparation and interaction with affected people, leading to smoother implementation of the agreed outcome (Creighton, 2005). Representatives of different stakeholder groups, including policy makers and implementers, professionals, academia, industry, non-governmental sector and general public are involved in the planning process as early as possible.

Public participation in decision making refers to the request that the public must be informed over all the relevant projects and it has to have the chance to participate during the decision-making and legislative process. Decision makers can take advantage from people's knowledge and expertise; this contribution is a strong opportunity to improve the quality of the environmental decisions, outcomes and to guarantee procedural legitimacy.

Public authorities are obliged to respect the public participation in decision making when preparing or implementing certain plans and programmes relating to the environment by the Århus Convention and Public Participation Directive $(2003 / 35 / E C)$. 
Participatory process: a process where we define our way of involving stakeholders in a desired field of action. We define purpose of the process, desired outcomes and results, activities and number of events that we will implement, who will be involved etc. Stakeholder involvement is defined by a participatory process, and its steps are explained in this handbook.

The difference that stakeholder involvement can make is shown in Figure 2.1. Good preparation from the start will save time and money later on. We want to take the time to collect best possible proposals and ideas so that we can more efficiently adopt best practices in planning aggregates supply policies. The aim is not only to prepare the policy; we will only be successful when we implement the well prepared policies. By gaining a wide consensus we ensure that the policies will not stay on the paper, but will be used and implemented by all involved. This means a shift from producing a plan or strategy in the shortest time to focusing on the process by which the plan is decided and ensuring it is acceptable to those whom it will affect. It is a shift from deciding for people to deciding with them.

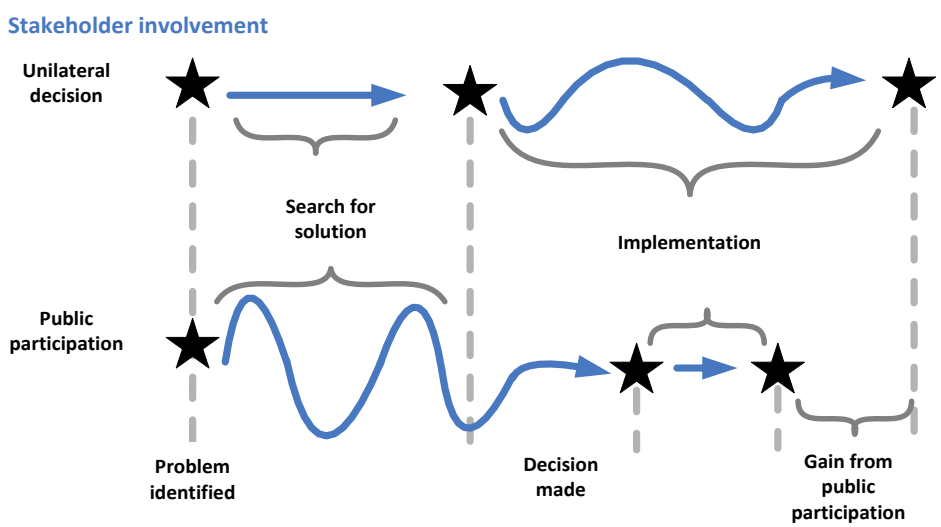

Figure 2.1: Difference between the traditional consultation and stakeholder involvement (adapted after Creighton, 2005)

\subsection{Benefits of Well Run Participation}

A well run participation process results in several benefits for all involved parties. At the end of the day, it leads to better informed and supported decisions that are affecting everyone's future, which results in a win-win situation as well as in saving time and money. Key benefits of a well planned and implemented stakeholder involvement process are: 
$\checkmark$ Well-informed decisions: a good process enables collection of different forms of knowledge on aggregates planning from participants: science, know-how, experience, values and perceptions.

$\checkmark \quad$ Lasting change: when those making decisions or implementing programmes involve other stakeholders in decision-making, and together decide on needed changes, they are more motivated to ensure positive outcomes and long-term benefits for all affected parties.

$\checkmark$ Ownership: the well implemented process generates buy-in and active support for implementation by all involved parties.

$\checkmark$ Real problems addressed: by involving stakeholders, solutions are based on an exploration of real needs and problems rather than those assumed by outsiders. Solutions are also assessed to make sure they do not cause a new set of problems for someone else.

$\checkmark$ Avoiding or managing conflict: by involving stakeholders at an early stage, when options are still open and flexible, it is possible to identify potential or actual conflict and actively work towards resolution.

$\checkmark$ Reduced costs: running a participation process costs money, but it pays off on the longer term in speedier and smoother implementation. It also saves time and money costs of persuasive PR materials and events, and can avoid the considerable monetary, time and reputation costs of legal processes (Pound, 2008).

The engagement of stakeholders in a participatory manner is an underlying principle in all actions taken in a process; it is not only a method or a technique used at an event for a certain purpose. The principles and values of stakeholder involvement on which facilitation is based (inclusiveness, transparency, openness and clarity, independence, commitment and responsiveness) should be taken into account in each step of the participatory process (The Environment Council, 2004).

\subsection{Ways of Involving Stakeholders}

There are different approaches of involving stakeholders into planning, decisionmaking and implementation processes affecting aggregates supply. We can talk about: (a) information giving, (b) information gathering, (c) consultation, and (d) shared decision making. In this model, one way of relating to stakeholders is not considered better than another. Each is seen to have value and is suitable for different purposes. The four categories are based on the extent that stakeholders influence the outcome; it is not a categorisation of an event style. It is possible to hold a fully facilitated participatory event in three of the categories:

$\checkmark$ Information gathering - where people have no influence over how the information is used (e.g. collection of feedback by a questionnaire); 
$\checkmark$ Consultation - where their views are passed to decision makers; or

$\checkmark$ Shared decision-making - where they are directly helping to make decisions themselves.

Whichever is used it is essential that stakeholders understand what is being asked of them and there is clarity about the extent to which they can influence decisionmaking. The type of relating to stakeholders chosen should reflect the purpose of the participation process. In clear and uncontroversial situations a press release can be used. In more complex and/or controversial situation investing time and money into a well-thought stakeholder dialogue can turn out to be a suitable approach (Pound, 2008). Details of each approach are presented in Figure 2.2.

To implement the integrative approach in practice, we should take into consideration that various stakeholders and their different views, opinions and approaches shall be brought together at one table in a facilitated process in order to agree on a long-term approach to sustainable aggregates planning. If we would like to act in a truly participatory manner, people should be asked for their views at the very beginning.

Benefits of involving stakeholders - experience of the SNAP-SEE project:

$\checkmark$ Stakeholders representing very different organisations came together and started talking to each other, in some cases for the first time.

$\checkmark$ Significant interest in participation at consultations and engagement at events was observed, even when a different reaction had been expected.

$\checkmark$ Cooperation was enhanced between authorities of different sectors, e.g. mining, environment, water, land use planning, transport etc. and at different levels (national, regional, local).

$\checkmark$ Awareness was raised about the importance of planning.

$\checkmark$ The need for preparing the national minerals policy was identified.

$\checkmark$ Key obstacles or problems faced in planning were identified (e.g. procedures, illegal quarrying, lack of awareness etc.).

$\checkmark$ Suggestions for solutions were proposed and were acceptable for the majority of involved groups.

$\checkmark$ Importance of recycling of aggregates was promoted.

$\checkmark$ A basis for future cooperation was set or enhanced.

Detailed information about the aggregates planning process can be found in other parts of the Toolbox for Aggregates Planning:

- A Vision of Best Practices for Aggregates Planning in South East Europe;

- How to Build a Sustainable Aggregates Plan; and

- Data and Analysis in Support of Best Practices in Sust. Aggregates Planning. 


\begin{tabular}{|c|c|c|c|c|c|}
\hline 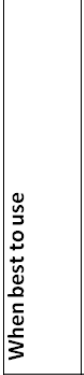 & 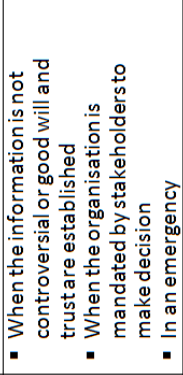 & 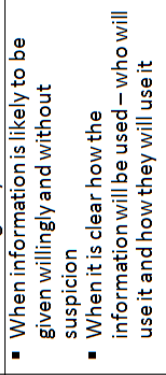 & 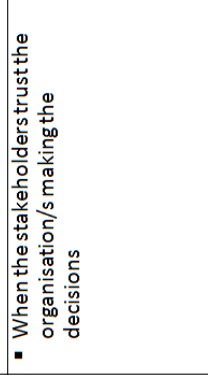 & 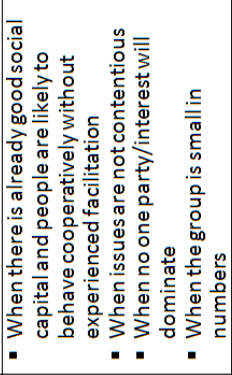 & 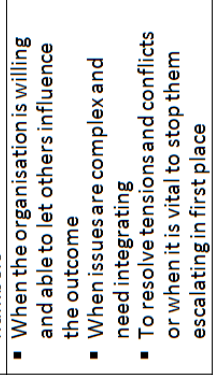 \\
\hline \multirow[b]{2}{*}{ 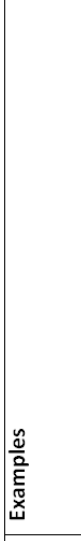 } & \multirow[b]{2}{*}{ 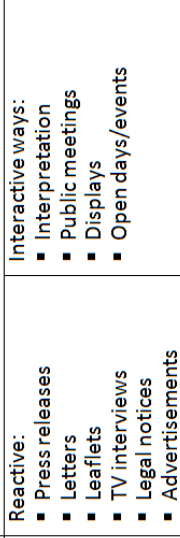 } & 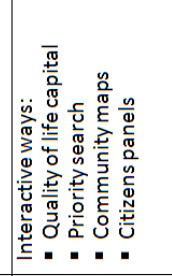 & 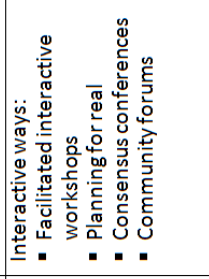 & \multirow[b]{2}{*}{ 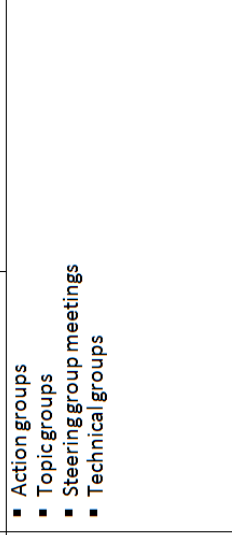 } & \multirow{2}{*}{ 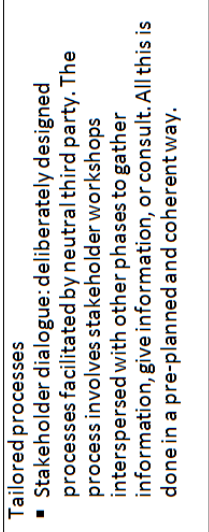 } \\
\hline & & 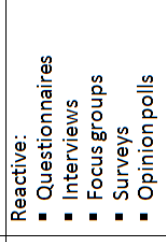 & 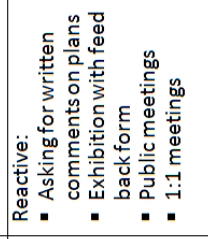 & & \\
\hline 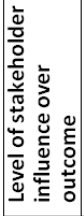 & 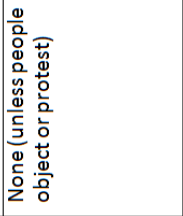 & 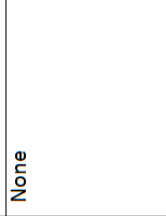 & 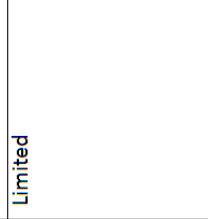 & 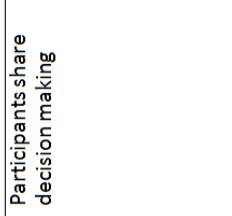 & 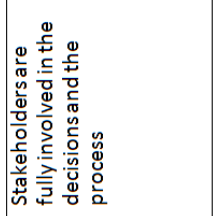 \\
\hline 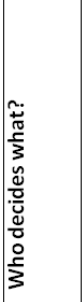 & 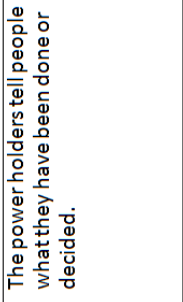 & 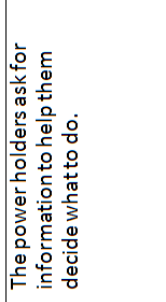 & 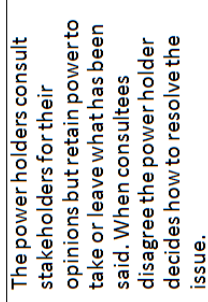 & 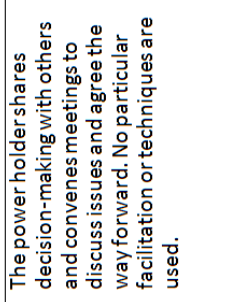 & 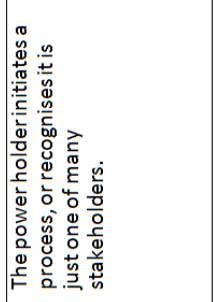 \\
\hline 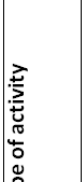 & 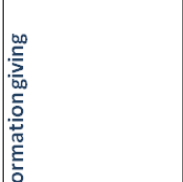 & مِ & 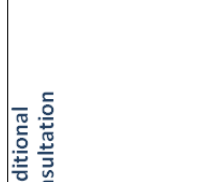 & 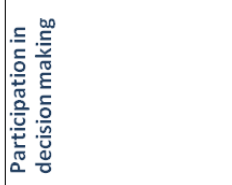 & 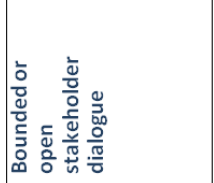 \\
\hline$\sum_{1}^{2}$ & 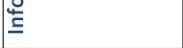 & 惫 & 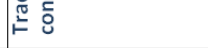 & & yеш ио!̣!эәр рәдечs \\
\hline & -1 & N & m & $\nabla$ & \\
\hline
\end{tabular}




\section{Planning the Participatory Process}

When we decide on improving a minerals/aggregates planning policy by honestly involving the stakeholders, we should carefully plan and define the process of their participation, purposes of such a process, the activities we will undertake and the roles of included people.

This chapter focuses on planning the participatory process, while the next chapters explain the analysis of stakeholders, and tips for planning and implementing the events in the process.

In the SNAP-SEE project, the overall aim of the consultation process was to achieve more sustainable supply of aggregates in participating countries or regions. The outputs for each country/region were the multi-sectoral analysis of the current approach to aggregates planning and national/regional guidance on improving aggregates planning. The achieved outcome included: better understanding of aggregates planning process, agreement on acceptable solutions, increased capacity on SARM and SSM concepts, and good practices in other countries, increased awareness of sustainable approaches, and increased knowledge of up-to date data and methods. 


\subsection{Before We Start}

Collaborative approach when involving stakeholders in aggregates planning means recognising that you are one stakeholder amongst many and for the best decisions to be reached other voices should take part in the discussion. When done well, there are many benefits in involving stakeholders, but organisations need to think carefully before doing so and ensure it is for the right reasons. Inviting people to participate in planning should be because there is a genuine opportunity for them to influence the outcome. Participation should not be used to confirm decisions that have already been made. If people think their time has been wasted in poorly run workshops, or their attendance makes no difference to the outcome, which is often the case, they will lose trust and respect for the organisations concerned.

If you are going to involve stakeholders you should be clear why you are doing this. If stakeholders will give time to your meeting or process, they should know what is happening, why they are being asked to get involved, what influence they can have over the outcome, and how the event relates to the overall decision-making process. There should be a genuine commitment to listen and consider what others say. Key people need to understand and support the use of this approach. There has to be enough time, skilled people and funding to run the process (Pound, 2008).

The key to a successful process lies in good preparation. Professionals say that the event itself is like a tip of the iceberg. It is estimated that as much as $80 \%$ of the effectiveness of a good process is in the preparation. The aim is to prepare well enough to ensure that what happens on the day of the event goes smoothly and makes a real difference to how people work together (Pound, 2008).

\subsection{Steps for Planning the Participatory Process}

Once we have decided to involve stakeholders in a participatory process aimed at sustainable aggregates planning, it is crucial to start with careful planning and preparation. Planning the participatory process contains several steps, if we plan a yearlong process or a single event. This and the following chapters explain five parts of effective planning of a participatory process:

1. Understanding the situation - purpose and outcomes

2. Process planning - action plan

3. Event design: planning, implementation and follow-up

4. Task or session planning

5. Practical organisation.

The parts are not in a straightforward sequence, but form an iterative process as each part feeds back and helps shape the design of the other parts. At each step in 
the process we have to keep in mind other parts and when necessary adapt the planned activities, as shown in Figure 3.1.

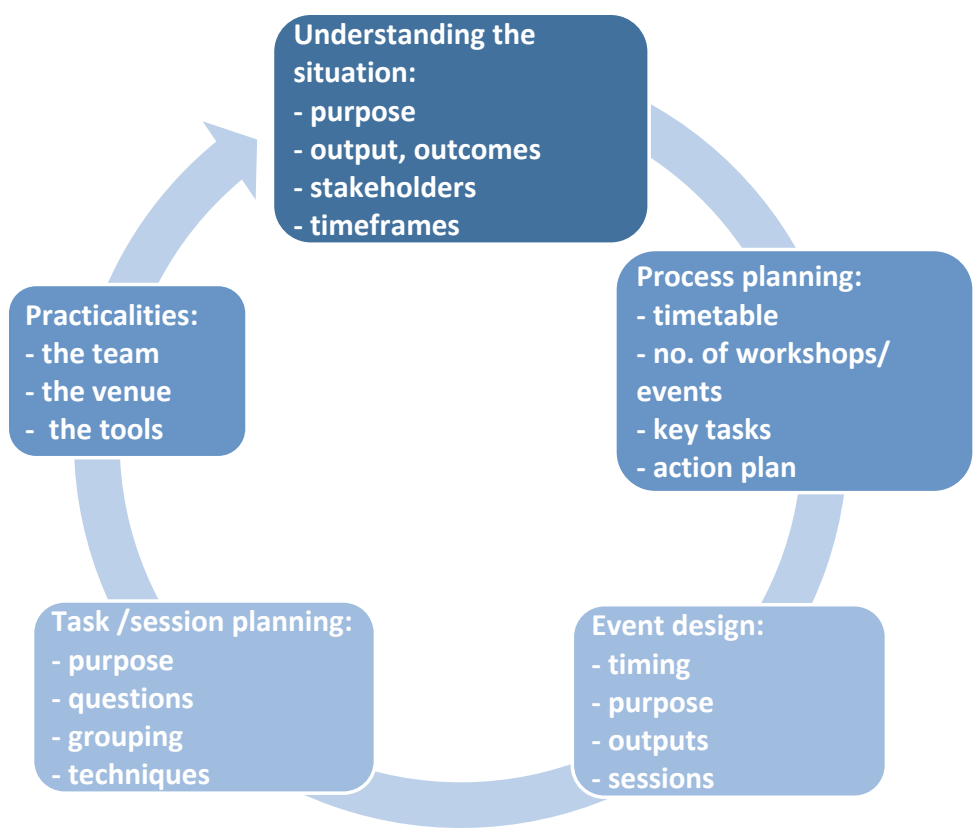

Figure 3.1: Steps for effective planning of a participatory process (Pound, 2008)

Key objective of the process planning is to provide the most effective process: fit for purpose, tailored to the needs of participants, the desired outcomes and the available resources.

\subsection{Purpose of the Participatory Process and Steps in the Process}

The points and questions in the table below are helping in clarifying the situation and the desired outcome of a process and should enable a good understanding before we start the process itself. The questions are leading you when defining the purpose of the whole participatory process - what do we want to achieve in what circumstances. 


\begin{tabular}{|l|l|}
\hline Defining the purpose of the process - leading questions (Pound, 2008) \\
\hline Purpose & $\begin{array}{l}\text { What is the primary purpose of this process/event? } \\
\text { What is realistic and achievable within the available resources, staff, time and } \\
\text { budget? } \\
\text { What do the initiators/problem holders hope to have by the end of the process } \\
\text { that they don't have now? } \\
\text { How will they know the process has been a success? What will it feel like, look } \\
\text { like? }\end{array}$ \\
\hline Outputs & $\begin{array}{l}\text { What are the hard products? } \\
\text { Examples: specialist report, action plan, a list of priorities }\end{array}$ \\
\hline Outcomes & $\begin{array}{l}\text { What do people want to change as a result of this process? } \\
\text { Relational outcomes include: better relationships, better understanding, more } \\
\text { buy in and ownership, active support, stronger teams, more trust, increased } \\
\text { cooperation, reduction in tension, better decisions } \\
\text { Content outcomes can be: better managed environment, more sustainable } \\
\text { use/development, agreement about best practice }\end{array}$ \\
\hline People & $\begin{array}{l}\text { Who is this process for? } \\
\text { Who should be involved and in what capacity? } \\
\text { Who are the stakeholders (see also chapter 4)? }\end{array}$ \\
\hline Content & $\begin{array}{l}\text { What is the focus of the discussion? } \\
\text { What are the issues, subjects, and concerns? } \\
\text { What needs to be solved? }\end{array}$ \\
\hline $\begin{array}{l}\text { Known deadlines - statutory, meetings, printing, funding etc. } \\
\text { Key events/happening relevant to the project, similar events, expected change } \\
\text { happening staff or organisation } \\
\text { Public events: public and religious holidays, elections, international sporting } \\
\text { events, local events } \\
\text { Constraints: busy season for stakeholders, holidays, end of fiscal year, availabil- } \\
\text { ity of staff in the organisation, the facilitator and team }\end{array}$ \\
\hline
\end{tabular}

Once we rethink all of the above, it should enable us a much clearer understanding of what the process is all about and to start planning the steps of the process more in detail. The participatory process can have different aims which results in different types of activities and tasks to be used between and at the events. To achieve the defined purpose, we should define smaller in-between objectives that will be achieved with smaller tasks of the process and the number of events that are needed to achieve the overall purpose and the interim objectives. In the majority of cases, the participatory process follows the next sequence of steps:

$\checkmark$ Analysing the situation, the problems, the reasons behind (i.e. what is the current state of planning, who is participating, who else should participate, what works and what should be improved etc.);

$\checkmark$ Defining a common vision - where do we want to be in the future;

$\checkmark$ Identifying solutions;

$\checkmark$ Analysing the feasibility of solutions and their acceptance by stakeholders; and

$\checkmark$ Selecting solutions and defining action planning (who will do what by when). 
A key part of stakeholder dialogue is that each event or process is designed and tailored to suit the situation. On the basis of the analysis as described above, we can define: (a) the overall aim of the process, (b) the number of events (workshops, smaller meetings etc.) and (c) key phases to be included in the process timeline.

When consulting for best practices in aggregates planning, the three key objectives of the participatory process are the following:

1. Capacity building of (key) stakeholders about the sustainable aggregates resource management (SARM) and assuring a secure sustainable supply mix (SSM);

2. Consultations with stakeholders about the existing situation: analysis of the current approach to planning, legislation, procedures, obstacles, gaps, bottlenecks etc.; and

3. Consultations with stakeholders about possible solutions: suggesting possible solutions to overcome the obstacles and define steps, timeline and responsibilities for their achievement.

The general process for support of best practices in sustainable aggregates planning is the following:

\begin{tabular}{|l|l|}
\hline \multicolumn{2}{|l|}{ Overall process planning for consulting stakeholders in the SNAP-SEE project: } \\
\hline $\begin{array}{l}\text { Setting the overall } \\
\text { aim }\end{array}$ & Achieving more sustainable supply of aggregates in my country/region \\
\hline $\begin{array}{l}\text { Setting the purpose } \\
\text { of the participation } \\
\text { process }\end{array}$ & $\begin{array}{l}\text { To analyse the existing situation in aggregates planning and look for solu- } \\
\text { tions to overcome existing obstacles in cooperation with representatives } \\
\text { of different target groups from all affected sectors } \\
\text { To create a roadmap for developing aggregates policy or making it more } \\
\text { sustainable, linking the supply from primary and secondary aggregates }\end{array}$ \\
\hline $\begin{array}{l}\text { Defining the key } \\
\text { stakeholders }\end{array}$ & $\begin{array}{l}\text { See chapter 4: Representatives of public authorities, expert organisations, } \\
\text { industry, local communities, NGOs and the media }\end{array}$ \\
\hline $\begin{array}{l}\text { Outputs of the con- } \\
\text { sultations }\end{array}$ & $\begin{array}{l}\text { Multi-sectoral analysis of the current approach to aggregates planning; } \\
\text { national/regional guidance on improving aggregates planning }\end{array}$ \\
\hline $\begin{array}{l}\text { Outcomes of the } \\
\text { consultations }\end{array}$ & $\begin{array}{l}\text { Better understanding of aggregates planning process and current limita- } \\
\text { tions, agreement on solutions, increased capacity on SARM and SSM con- } \\
\text { cepts, increased capacity about good practices in other countries, in- } \\
\text { creased awareness of sustainable approaches, increased knowledge of up- } \\
\text { to date data and methods }\end{array}$ \\
\hline $\begin{array}{l}\text { Defining the num- } \\
\text { ber of events }\end{array}$ & $\begin{array}{l}\text { It is recommended to implement at least two consultation events (work- } \\
\text { shops for capacity building, collecting information, identifying and analys- } \\
\text { ing solutions) where representatives of all involved sectors are present; in } \\
\text { between smaller meetings and meetings of the core group should be } \\
\text { planned }\end{array}$ \\
\hline Timing & \begin{tabular}{l} 
In general, approximately a year is needed to implement such process \\
\hline
\end{tabular} \\
\hline
\end{tabular}


Template 1 can be used for planning the purpose of the participation process.

Template 1: Purpose of participation process in my country/region

\begin{tabular}{|c|c|}
\hline Questions & Replies for the process in my country/region \\
\hline $\begin{array}{l}\text { What do we want to achieve at the end } \\
\text { of the process? } \\
\text { What are the expected results? }\end{array}$ & \\
\hline $\begin{array}{l}\text { What information do we want to share } \\
\text { or collect? } \\
\text { What would be the main messages? } \\
\text { How will the participants gain from the } \\
\text { process and events? }\end{array}$ & \\
\hline $\begin{array}{l}\text { What are the tangible outputs at the } \\
\text { end of the process? }\end{array}$ & \\
\hline $\begin{array}{l}\text { How will you use the outputs and re- } \\
\text { sults? }\end{array}$ & \\
\hline How many events do we plan to hold? & \\
\hline
\end{tabular}

\section{Purpose of the participation process - examples from the SNAP-SEE project con-} sultations:

$\checkmark$ To involve in the process of aggregates planning most of the important stakeholders such as national government, local authorities, private sector, civil society and communities.

$\checkmark$ To reach an agreement on aggregates exploitation plan that will guarantee sustainable development and increase possibilities for recycling.

$\checkmark$ To include secondary aggregates in aggregates planning as a potential source for development of infrastructure in an environmentally friendly manner.

$\checkmark \quad$ To be in line with strategic policies of the country and EU.

$\checkmark \quad$ To achieve synergy among different plans and strategies concerning aggregates.

After we have defined the steps that need to be taken, they should be considered within the time available to make sure we have sufficient amount of time to take care of each step. The next chapter describes how to define the timeline for implementation of the participatory process. 


\subsection{Timeline for Defining the Participatory Process}

After we decided on the overall objective of our process and the specific objectives of separate phases of the process, it is very useful to prepare a timeline where we put on a time scale:

$\checkmark$ Number and type of events that will be organised;

$\checkmark$ Interim smaller meetings;

$\checkmark$ Activities of the organising group before and after the events; and

$\checkmark$ Most appropriate timing according to the circumstances (holidays etc.).

The time plan table contains time scale in the top row (months available from starting the planning until we would like to conclude the process), and different types of activities/constraints at the left side. In the table we insert:

$\checkmark$ Project/other important milestones affecting our process;

$\checkmark$ Constrains, such as holidays, vacations, school holidays, other important events etc.;

$\checkmark$ Dates suitable for planned events in the process (workshops with stakeholders, smaller meetings etc.);

$\checkmark$ Activities of the coordination team; and

$\checkmark$ Activities with stakeholders.

Example of a table based on the plan of the SNAP-SEE project is shown below in Template 2. Detailed instructions for planning steps of the process and a single event are described in the following chapters, while the next chapter focuses on defining stakeholders. 


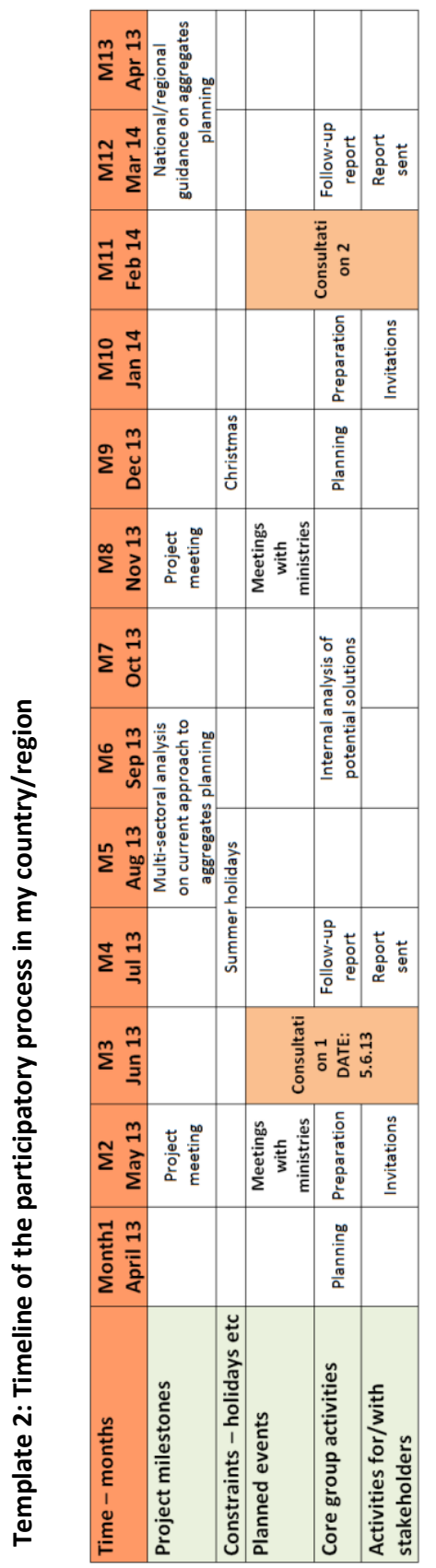




\section{Who are the Stakeholders and How to Involve Them}

Stakeholders can be defined as any person, group or organisation that is likely to be affected by, or have an interest in, the decisions being made. This comprises all organisations or persons that are in charge of aggregates planning, are affected directly by planning procedures, or are involved in or affected by quarrying, and pre-or post quarrying activities.

When we consider stakeholder involvement process, the first step is identification of different stakeholders. Of key importance is the second step, analysing the roles and interests of different groups, and on the basis of that, defining what we would like to achieve and what is the most suitable way of involving those groups. It is often thought to be the case that all stakeholders have to be included in the same way throughout the process; however, this is not the case. One of the steps when planning stakeholder involvement is to define which activities are most suitable for different groups to be involved, from information giving and gathering to consultation events. 


\subsection{Identification of Stakeholders in Aggregates Planning}

Stakeholders in aggregates planning are listed below by sector and by different types of organisations. We should keep in mind that the list of stakeholders (relevant organisations, groups and individuals) is never finished and the analysis is never concluded - it will at all times be rethought and if needed amended based on development of the process.

\section{Groups of stakeholders in aggregates planning by sector include:}

$\checkmark$ Quarrying and mining

$\checkmark$ Economy - enterprises and their representatives

$\checkmark \quad$ Land use/spatial planning

$\checkmark$ Waste management

$\checkmark$ Transport

$\checkmark$ Water management
Environment, nature protection, protected areas

$\checkmark$ Forestry

$\checkmark$ Agriculture

$\checkmark$ Public health

$\checkmark \quad$ Cultural heritage, archaeology

Table 4.1: Stakeholders by types of organisations

\begin{tabular}{|c|c|}
\hline $\begin{array}{l}\text { Government/authorities from all above } \\
\text { listed sectors: } \\
\text { - National government: ministries, agen- } \\
\text { - } \text { Regies, public institutes } \\
\text { - } \text { Local government: municipalities, re- } \\
\text { gional/local development agencies } \\
\text { - Inspectorates } \\
\text { - Other regulation bodies } \\
\text { - EU level bodies }\end{array}$ & $\begin{array}{l}\text { Aggregates industry: } \\
\text { - Quarry owners } \\
\text { - } \text { Puarry operators } \\
\text { - } \text { Workers and worker associations } \\
\text { - } \text { Associations - regional, national and } \\
\text { international } \\
\text { - Chambers of commerce } \\
\text { - } \text { Construction industry } \\
\text { - } \text { Uggregates consumers } \\
\end{array}$ \\
\hline $\begin{array}{l}\text { Experts: } \\
\text { - Geological surveys, research institutes } \\
\text { - } \quad \text { Ind similar } \\
\text { sectors (spatial planning, environment, } \\
\text { nature protection, waste management, } \\
\text { transport, water management, agricul- } \\
\text { ture, forestry etc.) } \\
\text { - Universities and other education or- } \\
\text { - } \text { ganisations } \\
\text { - } \text { Inining experts, geologists etc. } \\
\end{array}$ & $\begin{array}{l}\text { Communities and NGOs, voluntary sector: } \\
\text { - Land owners } \\
\text { - Local inhabitants, farmers } \\
\text { fields of environment protection, ecol- } \\
\text { ogists, bird protection etc. } \\
\text { - Civil associations }\end{array}$ \\
\hline
\end{tabular}


When thinking about stakeholders and how to identify the relevant ones for your events, these questions will guide you:

$\checkmark$ What organisations or individuals are in charge or have an interest in aggregates planning?

$\checkmark \quad$ Who are the people that represent them?

$\checkmark$ What is the information/knowledge that they need?

$\checkmark$ Who will be directly affected by the event/project results?

$\checkmark$ Who is directly responsible for making decisions on the discussed issues?

$\checkmark$ Who is influential in this topic/region/organisation?

$\checkmark$ Who has been involved in this issue in the past?

$\checkmark$ Who was not involved, but should have been involved?

$\checkmark$ Who are they key "movers and shakers" that can help further promote the results and decisions?

$\checkmark$ Who are the opponents or "blockers" of your ideas, initiatives that are better to be included in the process in general, rather than speak badly of your efforts outside of the process/project and thus giving it bad publicity?

We have to keep in mind the power of different groups or individuals to influence the decisions and the level of their interest in the topic concerned. These two categories form the basis for dividing stakeholders into different groups which will be approached in a different way in the process, which is explained in the next chapter.

\subsection{Grouping the Stakeholders by Roles}

The stakeholders with higher level of impact on taking decisions affecting aggregates planning (e.g. ministries in charge) should be involved in the process more actively than other groups listed above. This does not mean that their opinion will not be heard or taken into consideration, but on the other hand means tailoring the process to our possibilities for implementation and the desired outcome.

This way, according to the interest, role and level of involvement of different stakeholders, we can divide them into four different groups with different roles. 


\begin{tabular}{|l|l|}
\hline Group & Role \\
\hline $\begin{array}{l}\text { Coordination } \\
\text { team }\end{array}$ & $\begin{array}{l}\text { Representatives of the coordinating organisation(s), i.e. project partners } \\
\text { and observers from each country/region: cooperate in all project activi- } \\
\text { ties, define, plan and implement the participation process, organise } \\
\text { events, write texts and reports. They lead and implement the whole } \\
\text { process and prepare documents. }\end{array}$ \\
\hline Working team & $\begin{array}{l}\text { Representatives of key organisations in charge of aggregates planning for } \\
\text { primary and secondary aggregates: they provide input for preparation of } \\
\text { analyses and reports, and participate at events with stakeholders. They } \\
\text { have an active role throughout the process. Besides the events, smaller } \\
\text { meetings can be organised with them to assure proper planning, imple- } \\
\text { mentation and follow-up of the participation process and assure up-to- } \\
\text { date data for the reports. They give input to the documents and partici- } \\
\text { pate at events with stakeholders. }\end{array}$ \\
\hline $\begin{array}{l}\text { Representatives } \\
\text { of key groups of } \\
\text { stakeholders }\end{array}$ & $\begin{array}{l}\text { Representatives of different groups of stakeholders (sectors and types of } \\
\text { organisations) listed above, which represent also key decision-makers and } \\
\text { opinion makers. They are affected by aggregates planning activities, and } \\
\text { their voice has to be heard. Their crucial role is to provide their opinions } \\
\text { and information at the consultation events. If needed, they can be con- } \\
\text { sulted also in between. They participate at events. }\end{array}$ \\
\hline $\begin{array}{l}\text { General public } \\
\text { and the media } \\
\text { they are targeted by the general promotional activities, such as the pro- } \\
\text { ject website, articles, leaflets and brochure. They are informed about the } \\
\text { project. }\end{array}$ \\
\hline
\end{tabular}




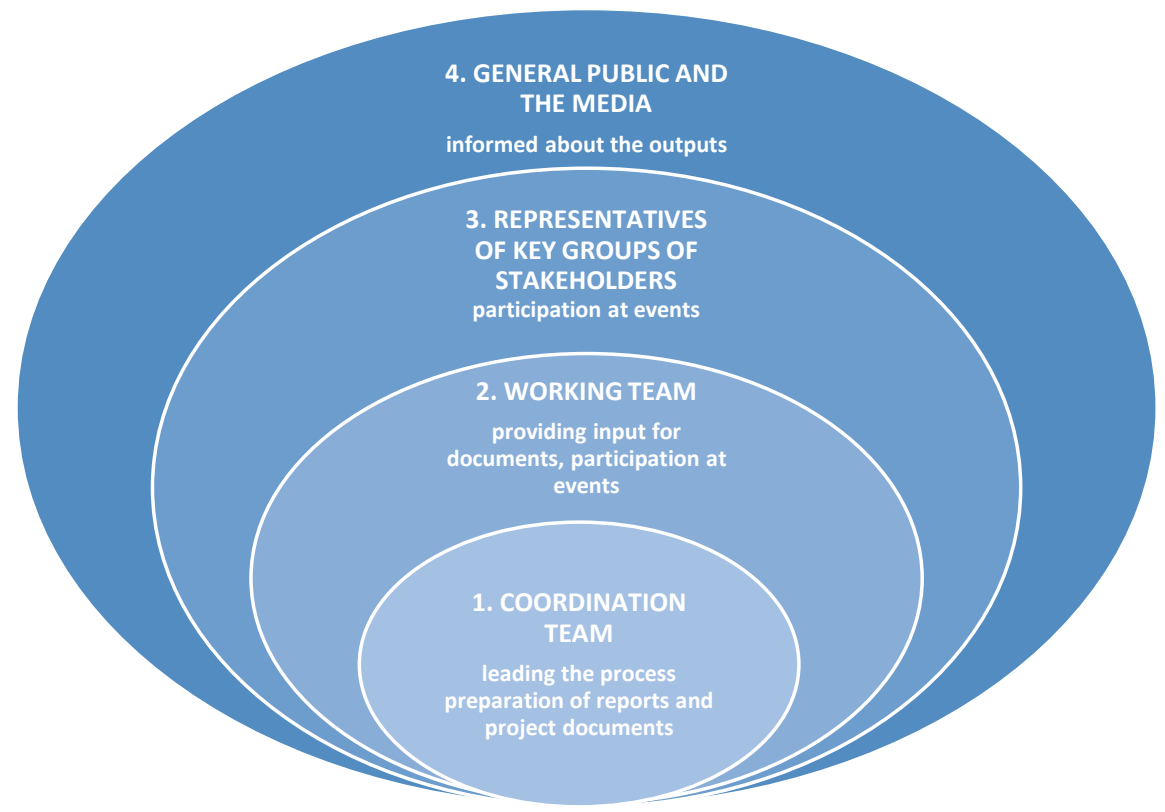

Figure 4.1: Grouping the stakeholders in four groups based on the level of their involvement

Each of the four groups has a different role and tasks. Tasks of the coordination team and the working team are explained more in detail in the following chapters.

When identifying and analysing stakeholder representatives, it is of key importance to identify not only the involved organisations, but also the persons that are in charge of or affected by the topic we are dealing with. The Template 3 below is included to list the key stakeholders, where you should take care to identify also the persons who will know the area or have a certain responsibility or opinion that should be heard. On the basis of this list of stakeholders, the contact list with addresses, e-mails and phone numbers of all relevant persons has to be prepared, to be used in all communication with stakeholders:

$\checkmark$ When collecting relevant information before the event or between the events;

$\checkmark$ For sending them invitations to the events;

$\checkmark$ For sending reports about implemented events;

$\checkmark$ For informing about the next steps in the process; and

$\checkmark$ To contact them about additional information needed. 


\section{Experience with involving different stakeholders in the SNAP-SEE project:}

$\checkmark$ The interests of different target groups vary widely. Their opinions differ a lot and can be opposite to each other. Therefore you need to carefully consider how to cooperate with all of them and how to avoid escalating conflicts. Some tips on moderating techniques are presented in chapter 6.

$\checkmark$ Representatives of different groups have shown interest in participating at consultations.

$\checkmark \quad$ It is crucial to identify not only the organisation in charge but also the right person dealing with the topic of the consultations.

$\checkmark \quad$ It is most challenging to motivate representatives of the authorities. It is essential to inform them about the benefits and the expected outcomes of the consultations.

$\checkmark \quad$ Industry is very motivated to cooperate and we must be careful that they are equally represented. They are most interested that the authorities assure stable and fair working conditions for their operations.

$\checkmark$ Expert organisations and experts from different areas will provide important insights into different themes.

$\checkmark$ Representatives of the environmental sector, NGOs and communities are also interested to be included in the dialogue from the start so that their opinions can be considered. Experience shows that they are not a priori against (quarrying) operations but they are too often left behind to the last stage of the process. 
Template 3: List of stakeholder organisations and contact persons

\begin{tabular}{|c|c|c|c|c|c|c|}
\hline $\begin{array}{l}\text { Type of organisa- } \\
\text { tion }\end{array}$ & $\begin{array}{l}\text { Organisa- } \\
\text { tion }\end{array}$ & $\begin{array}{l}\text { Belonging } \\
\text { to group } \\
1-4 \text { ? }\end{array}$ & $\begin{array}{l}\text { Contact } \\
\text { person }\end{array}$ & $\begin{array}{l}\text { E-mail } \\
\text { address }\end{array}$ & $\begin{array}{l}\text { Telephone } \\
\text { number }\end{array}$ & $\begin{array}{l}\text { Who } \\
\text { contacts } \\
\text { them }\end{array}$ \\
\hline \multicolumn{7}{|l|}{$\begin{array}{l}\text { National ministry } \\
\text { - mining }\end{array}$} \\
\hline \multicolumn{7}{|l|}{$\begin{array}{l}\text { National ministry } \\
\text { - environment }\end{array}$} \\
\hline \multicolumn{7}{|l|}{$\begin{array}{l}\text { Other relevant } \\
\text { national minis- } \\
\text { tries or agencies }\end{array}$} \\
\hline \multicolumn{7}{|l|}{$\begin{array}{l}\text { Regional govern- } \\
\text { ment }\end{array}$} \\
\hline \multicolumn{7}{|l|}{$\begin{array}{l}\text { Authority in } \\
\text { charge of waste } \\
\text { management }\end{array}$} \\
\hline \multicolumn{7}{|l|}{$\begin{array}{l}\text { Authority in } \\
\text { charge of } \\
\text { transport }\end{array}$} \\
\hline \multicolumn{7}{|l|}{$\begin{array}{l}\text { Authority in } \\
\text { charge of water } \\
\text { management }\end{array}$} \\
\hline \multicolumn{7}{|l|}{$\begin{array}{l}\text { Authority in } \\
\text { charge of ... }\end{array}$} \\
\hline \multicolumn{7}{|l|}{$\begin{array}{l}\text { Institutes, re- } \\
\text { search organisa- } \\
\text { tions, universities }\end{array}$} \\
\hline \multicolumn{7}{|l|}{$\begin{array}{l}\text { Representatives } \\
\text { of local authori- } \\
\text { ties }\end{array}$} \\
\hline \multicolumn{7}{|l|}{ NGOs } \\
\hline \multicolumn{7}{|l|}{$\begin{array}{l}\text { Representatives } \\
\text { of local communi- } \\
\text { ties }\end{array}$} \\
\hline$\ldots$ & & & & & & \\
\hline
\end{tabular}




\section{Planning an Event with Stakeholders}

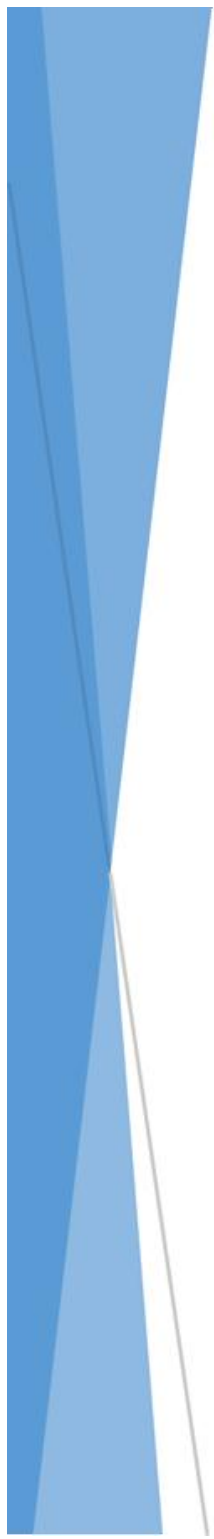

After we have decided on the key aspects of the participatory process, i.e. the purpose, the stakeholders, and the number of events and their timing, we can start planning the details of the first event. Previous chapters focused on key parameters that define the overall process, while the next chapters contain practical advice for implementing an event, i.e. a workshop, seminar or meeting with representatives of stakeholders. This chapter presents details for organising an event: timeline, team, right time and place, agenda and invitations.

In the SNAP-SEE project, 20 consultation events were organized in 10 countries, with over 800 participants from 90 organizations, representing all target groups. This chapter summarizes the experience of organizing such events, while details are presented in the final project publication (accessible at the http://snapsee.eu). It is crucial to start planning early enough, prepare well, allocate tasks between the team members, and assure the follow-up after the event. All this will contribute to successfully achieving the aim of an event, i.e., finding common solutions for better aggregates planning. 


\subsection{Timeline for Organisation of an Event}

Key activities for organisation of an event are summarized in Figure 5.1. They are structured in the time sequence: what has to be done before the event, at the event and after the event.

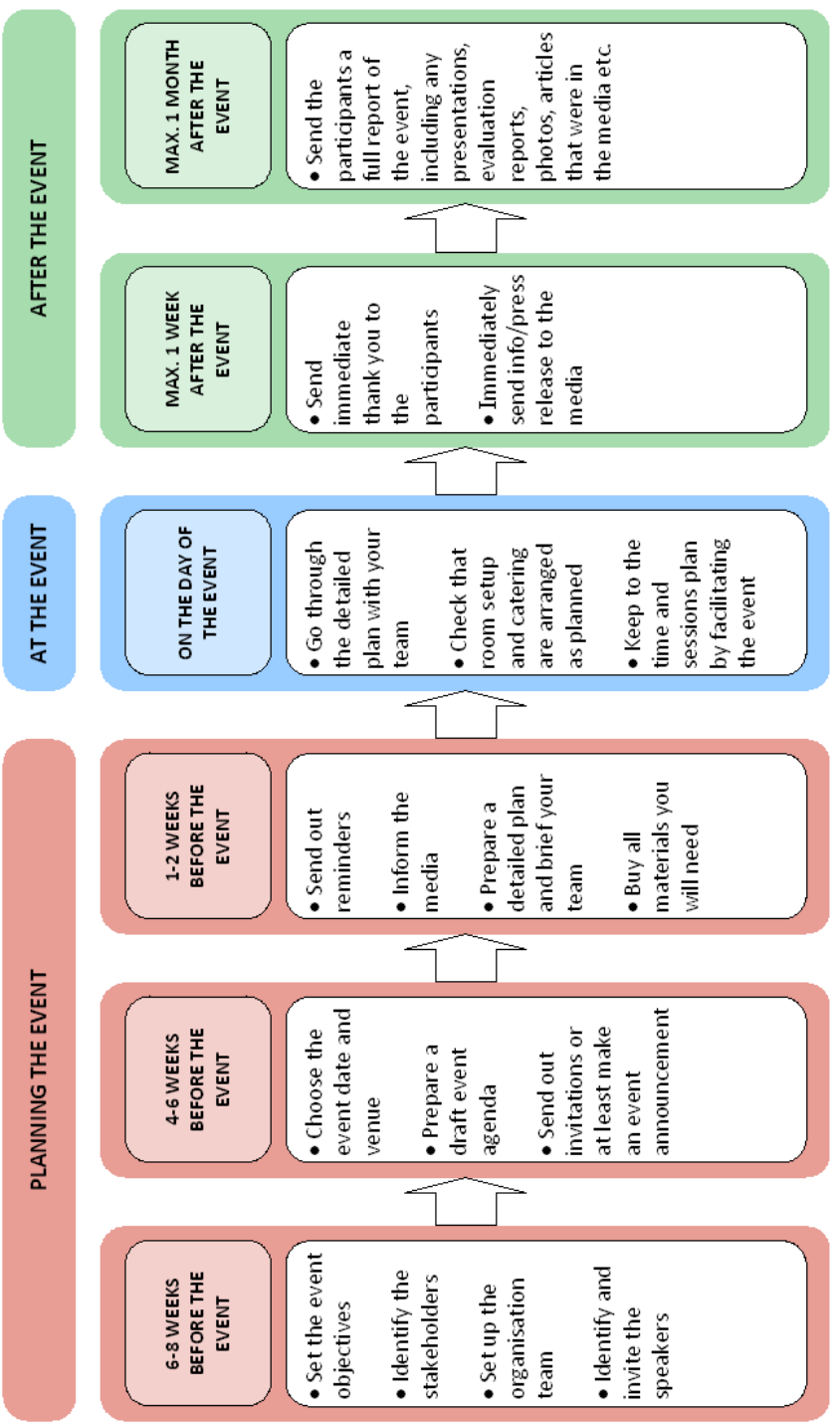

Figure 5.1: Timeline for organisation of an event with stakeholders (Softić et al., 2011) 


\subsection{Who is on My Team}

Organising a meeting or workshop with stakeholders contains a number of activities. Therefore it is recommended to form a coordination team and allocate the tasks between several team members. First of all, someone in the organisation should be appointed who will be in charge of the event. Even if you decide to outsource the event organisation to external experts, you should always appoint the lead organiser in-house to oversee their work and be in contact with them for any issues. When thinking about distributing tasks between team members, the main tasks you should plan are listed below when preparing the event, implementing it and after it.

\begin{tabular}{|c|c|}
\hline Phase & Main tasks \\
\hline $\begin{array}{l}\text { Preparing the } \\
\text { event }\end{array}$ & $\begin{array}{l}\text { - Preparing the content and detailed programme of the event } \\
\text { - Preparing invitations, other information materials } \\
\text { - } \text { Inviting the speakers, arranging the presentations } \\
\text { - } \text { Booking the venue, arranging catering } \\
\text { - } \text { nolists, event notifications at different websites) } \\
\text { - } \text { badges or labels etc.) } \\
\text { - } \text { etc.) } \\
\text { - Planning the budget and making payment arrangements with your ac- } \\
\text { counting/legal department }\end{array}$ \\
\hline At the event & $\begin{array}{l}\text { - Appoint the person who will be in charge of coordinating the event on } \\
\text { - } \text { site and taking all necessary last minute decisions on any changes } \\
\text { - } \text { handouts } \\
\text { Reception of speakers, taking their presentations, putting them on lap- } \\
\text { - } \text { Rooms lprojectors } \\
\text { - Managing paper and other materials } \\
\text { - Making arrangements regarding catering } \\
\text { - Putting up posters } \\
\text { - } \text { Facilitation of the event } \\
\text { - Recording the discussions } \\
\text { - Cleaning up the place after the event } \\
\text { - Taking care of payments, invoices }\end{array}$ \\
\hline $\begin{array}{l}\text { After the } \\
\text { event }\end{array}$ & $\begin{array}{l}\text { - Prepare a report on the event and send it to participants and other } \\
\text { invitees } \\
\text { - Send thank you letters to guest speakers } \\
\text { - Write and send a press release to the media } \\
\text { - Identify other follow-up tasks related to the event as such or to the } \\
\text { project (e.g. information for project reports) }\end{array}$ \\
\hline
\end{tabular}


To distribute the roles and set deadlines you can use the Template $\mathbf{4}$ for defining responsibilities of involved team members.

\section{Template 4: Responsibilities of the coordination team}

\section{COORDINATION TEAM}

Person responsible for organisation:

Other team members and tasks:

\begin{tabular}{|l|l|l|}
\hline Person & Tasks & Deadline \\
\hline$\ldots$ & $\ldots$ & $\ldots$ \\
\hline & & \\
\hline
\end{tabular}

\subsection{Choosing the Right Time and Place for the Event}

In order to move on with the planning and to prepare invitations, the next step is to decide on the time and place of the event.

Duration of the event: there is no rule about how long the event should be. The most important thing is that you know what you want to say to the participants and that you plan enough time to do so. So you might plan a whole day event, or a series of shorter events and smaller meetings with key stakeholders. In order to organise a comprehensive workshop, we recommend planning a one-day event. Such were also the SNAP-SEE consultation workshops, which lasted between 4 and 8 hours. In the table below some more considerations regarding the date and place are presented.

\section{The date of the event}

- What else is going on at that time - try to avoid school holidays, long weekends due to public holidays in the middle of the week, important events at the national/regional level such as election period, or other popular events like the World Cup or Olympic Games.

- Are there any similar events targeted at the same audience that are taking place in the same time - speakers might be already booked and participants will not go to a similar event in a week or two.

- On the other hand - in justified cases you may want to use the opportunity and join your event with another event on the same topic.

\section{The place of the event - location}

- Transport connections to the location is it easy to access? Is there public transportation available? Are there enough parking spaces?

- How long are meeting rooms available?

- Is the meeting room big enough for the expected turnout?

- Is the room too big?

- If we will hold workshops where people will be separated into groups - is there enough space for setting up more work groups?

- Is there a place where the registration table can be placed?

- Check if the location has the necessary technical equipment or if you have to bring your own. 


\subsection{Event Purpose}

Defining the overall purpose of the consultations process was explained in chapter 3. Before we organise the first event, we should reconsider its purpose and the target audience, which will be followed by defining the structure and speakers at the event.

Defining the purpose is a crucial first step that will guide us through the whole process and will be a basis for choosing the right audience and selecting the best methods of presentation or cooperation of participants. In order to pinpoint the purpose of an event, here are some questions to help you. So, before you send out any invitations sit down with your team members and think about these questions:

$\checkmark \quad$ What do you want to achieve at the end of an event - what are the expected results (e.g. key stakeholders informed about the project and its results; increased capacity on SARM, SSM and other relevant topics; agreed key steps and responsibilities to prepare the national minerals plan).

$\checkmark$ What information do you want to share, what should be the main message of the event? How will the participants benefit from the event? (e.g. employees at the national ministries will gain better knowledge of SARM \& SSM, of data and methods, of good case examples in other countries).

$\checkmark$ What tangible outputs/products do you want to get at the end of the event/what information do you want to receive back from the participants (e.g. a list of bottlenecks in implementation of current procedures for concessions, list of obstacles preventing using recycled aggregates).

$\checkmark$ How will you use the results/the outputs of the event (e.g. for preparation of recommendations for national/regional government).

Different needs of stakeholders affect the way things will be communicated to each of them at events. That is why it is important to better understand your target groups, as described in chapter 4. Finally, it is time to define the date, location, purpose and other key information of the first consultation event in the Template 5.

Template 5: Key information for the first consultation event

\begin{tabular}{|l|l|}
\hline KEY INFORMATION FOR THE FIRST EVENT \\
\hline Date of the event: & \\
\hline Location, venue: & \\
\hline Purpose of the event and event type: & \\
Is it a seminar, sharing information? Is & \\
it a place for collecting opinions? Is it & \\
meant to collect ideas and sugges- & \\
tions? Is it a combination of them? & \\
\hline Duration: & \\
\hline Expected number of participants: & \\
\hline
\end{tabular}




\subsection{How to Structure the Event}

Once we have defined the purpose of the event, we can start planning the detailed structure. There are several possibilities how to best structure the event. Usually we use one of the three possibilities or a combination of them, which was also the case for the SNAP-SEE consultations:

\section{$\checkmark$ General presentations and capacity building presentations;}

$\checkmark$ Moderated discussion: to collect input from the participants we can prepare questions for moderated discussion; and

$\checkmark$ Workshop with active participation of attendees: we can use different methods to encourage active input of the majority of participants and make their opinion heard.

\subsubsection{General Presentations}

General presentations are used to start the event and to present a certain topic to the participants. Usually the event starts with the presentation of the framework, e.g. the project within which it is organised, as well as at which point the project is and how the workshop will contribute to its implementation. The introductory part focuses on the following:

$\checkmark \quad$ To provide key information about the project, main aims and expected results of the project;

$\checkmark$ To inform the participants regarding the stakeholder involvement process, its aims, the point at which the process is; and

$\checkmark$ To inform the participants what is the desired outcome of the workshop and how their input will be used.

\subsubsection{Capacity Building Presentations}

One of the aims of the SNAP-SEE project was to increase capacity of stakeholders in certain topics. If we would like to make the aggregates planning approach more sustainable, it is important to address the relevant people and bring the knowledge closer to them. For this reason in the project several capacity building presentations on different topics were prepared in English language and translated to 11 national languages of the SEE countries. They are listed in the box below and available for download at the project website http://snapsee.eu. 
List of capacity building presentations available to be used in English and languages of the South East Europe:

1. Sustainable Aggregates Planning in South East Europe (presentation of the SNAP-SEE project and preceding SARMa project)

2. Providing a Sustainable Supply Mix (SSM) of Aggregates

3. Legal and regulatory framework for aggregates supply at the EU level

4. Aggregates: Planning - Demand-Data-Green Public Procurement

5. Recycling of aggregates and related data

6. Aggregate Intelligence System \& Geographic Information System to support resource efficiency; example of a GIS system

7. Material flow accounts

8. Aggregates demand forecasting

9. Decision modelling

10. EU Green Public Procurement (GPP) Policy and Road Criteria

11. Sustainable Aggregates Planning - Life-cycle approach

\subsubsection{Moderated Discussion}

The second aim of the consultations is to collect feedback on different aspects of aggregates planning from the event participants. This can be done by moderated discussion or in interactive workshops with participants. Choice of method depends on several characteristics: number of participants, desired outcome, skills of the moderator/facilitator etc. Comparison of both methods is shown below.

If we would like to have discussion with/of all participants, we have to prepare well to moderate it in a suitable manner to achieve the replies to questions we would like to know. Suggestions for moderating the discussion include:

$\checkmark$ Get to know the audience well - who do you expect to participate, what will be their opinions? What is it about the event that attracts them? What questions are they hoping to find answers to?

$\checkmark$ Allow sufficient time for advance preparation, including the current happening in the field, the expertise of speakers and broad knowledge of the topic.

$\checkmark$ Choose carefully the discussion moderator - someone with experience and knowledge about the topic.

$\checkmark$ Prepare open-ended questions in advance that represent issues the audience will be interested in.

$\checkmark \quad$ Rather than ask every question yourself, allow the speakers and participants discuss the open issues.

$\checkmark \quad$ The role of the moderator is to guide the conversation, maintain an appropriate tone, keep people on task, and ensure everyone gets ample time to 
present his or her point of view. The moderator is not there to give a formal presentation or state their opinions.

At the SNAP-SEE consultations, the topics for discussion were linked to the overall purpose: what should be done to make the aggregates planning in our country/region more sustainable. This includes the following questions:

$\checkmark$ What is the current state of planning; what are issues, bottlenecks, gaps?

$\checkmark$ Who is in charge for aggregates planning? Do different authorities cooperate with each other? If yes, how does it work? If not, why not? Who is blocking cooperation?

$\checkmark \quad$ What are the procedures like? Are they too slow? If yes, why?

$\checkmark \quad$ What are the key obstacles as seen by the industry?

$\checkmark$ What are the key problems perceived by NGOs, local communities and inhabitants?

$\checkmark \quad$ What are the suggestions to overcome these obstacles?

$\checkmark \quad$ What cases from other countries could be used as a model (suitably adapted to the situation of the other country/region) to solve the problems?

$\checkmark$ Which solutions should be implemented, under which conditions, by

\subsubsection{Workshop with Active Involvement of Participants}

Another possibility is to organise a part of the event in a more interactive way - to divide participants in a number of groups and collect feedback in each group separately. This approach is suitable for smaller events (up to 50 people) since a higher number of moderators/facilitators is needed. First we will take a look at the comparison between plenary session (presentations or moderated discussion) and interactive workshop.

\section{COMPARISON BETWEEN WORKING IN PLENARY AND WORKING IN SMALL GROUPS}

Working in plenary is effective for giving presentations, but does not work so well if the goal is to have an in-depth discussion. Trying to hold discussion in plenary has the following disadvantages:

$\checkmark$ A few people will dominate - most will not participate.

$\checkmark$ The larger the group, the fewer the people who are assertive enough to speak up.

$\checkmark \quad$ Those who do speak up will feel constrained in what they say. 
Working in small groups is better in the following circumstances:

$\checkmark$ When the group is too large for everyone to have their say.

$\checkmark$ When in-depth discussion is needed.

$\checkmark$ To allow people who are less confident to speak up.

$\checkmark$ To build more trust and understanding between the stakeholders.

When planning work in groups keep in mind that participants will work best in groups of 7 to 10 individuals. Participants can sign up for the group in which they want to be or you can allocate people on the basis of techniques described in chapter 6 .

\section{How to run an interactive workshop}

Before starting the workshop you have to decide whether you will divide participants in groups, and how many groups you will make and then choose the technique with which you will collect the information and later present the results of the workshop to all participants. After the grouping you should use the technique which will enable you to get to get as much answers, ideas and prepositions as possible on one particular thematic. At this point you have to be careful on the following:

$\checkmark$ Be clear on the purpose of the workshop; what are expected outcomes.

$\checkmark$ Clearly define the questions that you want the participants to answer.

If you have different, but related, questions and you want the answers from all participants to all questions then here are two methods that are quite easy to do and allow you to get a lot done in little time - carousel and world café. More details are described in chapter 6 .

At this point it is time to think about the structure of the event with stakeholders. What will be its parts? How will they follow each other? Who will be the speakers? What do we want to discuss? What do we want to know at the end of the discussion? Do we need any materials, such as handouts, questionnaires, flipchart paper and pens etc.? The answers should be provided in the Template 6 below.

Template 6: Structure of the event

\begin{tabular}{|c|c|c|c|}
\hline \multicolumn{4}{|l|}{ STRUCTURE OF THE EVENT } \\
\hline Part of the event & Title, aims & Potential speakers & Materials needed \\
\hline Introductory presentations & & & \\
\hline Capacity building session 1 & & & \\
\hline Capacity building session 2 & & & \\
\hline Capacity building session 3 & & & \\
\hline Discussion/collecting input session 1 & & & \\
\hline Discussion/collecting input session 2 & & & \\
\hline$\ldots$ & & & \\
\hline
\end{tabular}




\subsection{Preparing the Agenda and Invitations}

So far we have defined the key parameters of the event - purpose, time, location and sessions. It's time to prepare the agenda and invitations for participants.

\subsubsection{Event Agenda}

When preparing the event agenda, you should firstly set the start and end time take into account how much time it will take for the participants to reach the event location and how much time will you need before the event in order to set up the room. The next step is to block out fixed times - at any event you always need time for breaks, starting and finishing activities and introductory presentations.

\section{Breaks}

Breaks are an integral part of any event. They are necessary because:

$\checkmark$ They provide the time for the participants to mingle informally.

$\checkmark \quad$ They break the ice and enable time for informal conversations or for continuing some discussions that were already started during the sessions - this is especially relevant during joint lunches.

$\checkmark \quad$ They give participants the chance to take a break and have a rest between topics and sessions, improving their concentration and energy.

\section{Starting and finishing activities}

At the beginning of each event plan time for:

$\checkmark$ Time for gathering of participants, registration;

$\checkmark \quad$ If possible have some tea/coffee or refreshments available during the registration time - this gives the participants the opportunity to already engage in informal conversation which can help build a good working atmosphere and builds trust between the participants;

$\checkmark \quad$ Welcome addresses by representatives of the hosting organisations and important guests - for example the mayor of a municipality, representative of a ministry in charge of the topic of the event etc.;

$\checkmark$ For presenting the facilitator(s) and the speakers;

$\checkmark$ To go through the agenda and outline the course of the event, pointing out also when the breaks will take place, where the refreshments will be served, where the toilets are, and any relevant safety information;

$\checkmark \quad$ To explain how the event will be run, especially if you plan interactive workshops - explain how the work in group will be organised, who will facilitate the work groups etc.;

$\checkmark$ To explain the materials that you handed out to them; and 
$\checkmark \quad$ If the group is small enough and you plan an interactive event it is good to have an introductory round so that the participants can introduce themselves. Otherwise you can do this later when people are working in groups.

At the end of each event you need time for:

$\checkmark$ Making event conclusions;

$\checkmark$ Explaining the next steps - when will they receive a report of the event, what are the next deadlines;

$\checkmark \quad$ If relevant - when will the next event take place; and

$\checkmark$ Closing words - thanking the participants for coming.

After we have planned all this we can see what time we have left for the sessions that will focus on the event topic. In the Template $\mathbf{7}$ below you can see an example of how the agenda can be built.

Template 7: Agenda of a SNAP-SEE consultation event

\begin{tabular}{|c|c|c|}
\hline Timing & Topics & Speakers \\
\hline $9.00-9.30$ & Registration and welcome tea/coffee & \\
\hline $9.30-9.40$ & Welcome address & Speaker 1 \\
\hline $9.40-9.50$ & $\begin{array}{l}\text { Introduction, presentation of the agenda, of the } \\
\text { speakers, how the day will work }\end{array}$ & Moderator \\
\hline $9.50-10.05$ & $\begin{array}{l}\text { Presentation of the project/the reasons for the par- } \\
\text { ticipation process }\end{array}$ & Moderator \\
\hline $10.05-10.20$ & $\begin{array}{l}\text { SNAP-SEE project in my country/region - main activi- } \\
\text { ties and results, aims of the consultations }\end{array}$ & Speaker 2 \\
\hline $10.20-10.40$ & Capacity building sessions 1 and 2 & Speakers 3, 4 \\
\hline $10.40-11.00$ & Coffee break & \\
\hline $11.00-11.30$ & Capacity building sessions 3 and 4 & Speakers 5, 6 \\
\hline $11.30-12.30$ & $\begin{array}{l}\text { Discussion/collecting input session 1: Topic } 1 \text { (discus- } \\
\text { sion or group work on a specific topic) }\end{array}$ & $\begin{array}{l}\text { Moderator or } \\
\text { facilitators }\end{array}$ \\
\hline $12.30-13.30$ & Lunch break & \\
\hline $13.30-14.15$ & $\begin{array}{l}\text { Discussion/collecting input session 2: Topic } 2 \\
\text { (discussion or group work on a specific topic) }\end{array}$ & $\begin{array}{l}\text { Moderator or } \\
\text { facilitators }\end{array}$ \\
\hline $14.15-14.40$ & Reporting from the groups and joint discussion & $\ldots$ \\
\hline $14.40-15.00$ & Closing session & $\ldots$ \\
\hline 15.00 & Finish & \\
\hline
\end{tabular}

We have defined the outline of the event. Even though we might not have the detailed plan of each of the sessions, we know the issues and topics that we want to discuss and the next step is to prepare and send out invitations. 


\subsubsection{Invitations}

A tempting invitation is key to the success of the event. A clear, short, concise, but at the same time explanatory, invitation should raise the people's curiosity in your topic and tempt them into coming. You can have a great programme planned out and you can have important and relevant things to say, but all these will remain untold if they are not well communicated to the targeted participants.

A well prepared invitation should include:

$\checkmark$ Title of the event;

$\checkmark$ Short background information about the event - is it part of a larger process, which is it and how does this event fit into it;

$\checkmark$ Who is the target audience and what will they gain by attending the event;

$\checkmark$ What is the aim of the event, what are the expected outcomes, how will they be used further on and by whom;

$\checkmark$ The event agenda;

$\checkmark$ Information about how and where to register and deadlines for registration;

$\checkmark$ Contact details where the participants can get additional information about the event - list both e-mail and telephone of the contact person;

$\checkmark$ Information about the venue and (if relevant) how to reach the venue and any other necessary logistic information.

There is no magic formula for writing a good invitation. The important thing is that you tailor the invitation to your targeted audience, using fluent and easy-tounderstand language.

Take enough time to plan everything for the event:

$\checkmark$ Start preparing a national/regional event 6-8 weeks before the event.

$\checkmark$ Send out invitations or at least a short announcement of the event 4-6 weeks before the event.

$\checkmark$ Send a reminder and a detailed agenda (if not sent before) to all invitees 1-2 weeks before the event and again 2 days before the event.

$\checkmark \quad$ For an international event you should start planning up to 6 months before in order to get the desired speakers and especially if you plan to have an expert conference where you want to also have expert articles presented; send out the invitations 3 months before; don't forget to send out reminders when the event gets closer -1 month before and 2 weeks before for last minute registrations. 


\subsection{Detailed Plan of the Event}

After you have sent out the invitations you can focus your attention on preparing a detailed plan of the event. This actually means preparing a scenario of how the event will be implemented so that everyone on the team can be on the same track. It also means defining more detailed topics for discussion and/or choosing the techniques and methods of work in interactive workshops. When you have clarified all these issues you should write down the detailed plan and make sure everyone on your team has it. A Template 8 table with detailed plan of the event can be found below.

Template 8: Detailed plan of a half-day event

\begin{tabular}{|c|c|c|c|}
\hline Time slot & Topic and used techniques & Who & Materials \\
\hline $8.00-9.00$ & $\begin{array}{l}\text { Room set-up: } \\
\text { - Putting up posters } \\
\text { - Preparing the table for registration } \\
\text { and materials for participants } \\
\text { - Preparing the computer and projec- } \\
\text { tor and saving PPT presentation on } \\
\text { the computer etc. }\end{array}$ & $\begin{array}{l}\text { Whole } \\
\text { team }\end{array}$ & $\begin{array}{l}\text { - Posters } \\
\text { - Attendance list } \\
\text { - Materials } \\
\text { - Laptop } \\
\text { - Projector } \\
\text { - Flipchart paper } \\
\text { - Etc. }\end{array}$ \\
\hline $9.00-9.30$ & $\begin{array}{l}\text { Registration and welcome coffee } \\
\text { - Giving participants attendance list } \\
\text { for signing } \\
\text { - Handing out materials } \\
\text { - Serving coffee and biscuits }\end{array}$ & $\begin{array}{l}\text { Team } \\
\text { member } \\
\text { Catering } \\
\text { service }\end{array}$ & $\begin{array}{l}\text { - Materials } \\
\text { - Attendance list }\end{array}$ \\
\hline & $\ldots$ & & \\
\hline \multirow[t]{2}{*}{$9.40-9.50$} & $\begin{array}{l}\text { Introduction, presentation of the } \\
\text { agenda, of the speakers, how the day } \\
\text { will work }\end{array}$ & $\begin{array}{l}\text { Main facil- } \\
\text { itator }\end{array}$ & - PPT with agenda \\
\hline & $\ldots$ & & \\
\hline \multirow[t]{2}{*}{$\begin{array}{l}10.20- \\
10.40\end{array}$} & Capacity building sessions 1 and 2 & $\begin{array}{l}\text { Speaker } 1 \\
\text { Speaker } 2 \\
\end{array}$ & $\begin{array}{l}\text { - PPT } \\
\text { - Handouts? }\end{array}$ \\
\hline & $\ldots$ & & \\
\hline $\begin{array}{l}11.00- \\
12.30\end{array}$ & $\begin{array}{l}\text { Session 1: Topic } 1 \\
\text { Part 1:, technique: Carousel: Work in } 3 \\
\text { groups; questions for the groups: } \\
\text { - Question } 1 \\
\text { - Question } 2 \\
\text { - Question } 3 \\
\text { Part 2, technique: Prioritising with dots }\end{array}$ & $\begin{array}{l}\text { Main facil- } \\
\text { itator } \\
\text { Facilitators } \\
1,2,3\end{array}$ & $\begin{array}{l}\text { - } \text { Flipchart paper }-5 \\
\text { per group } \\
\text { - } 3 \text { different colour } \\
\text { pens } \\
\\
\text { - Coloured dots } \\
\text { - } \quad \ldots .\end{array}$ \\
\hline & $\ldots$ & & \\
\hline $\begin{array}{l}12.30- \\
13.00\end{array}$ & Finishing the event & $\begin{array}{l}\text { Main facil- } \\
\text { itator }\end{array}$ & - Conclusions \\
\hline
\end{tabular}


You can make this plan as detailed as you need it - you can add detailed description of each step for each single technique. That will be very useful especially when you are using some technique for the first time. Revise the plan after a couple of days and work out plans B and C in case you foresee any problems - for example if less participants come than planned and you will not be able to work in groups - what can be an alternative?

\section{Planning the consultations event - experience of the SNAP-SEE project:}

$\checkmark$ We need to start planning the event well enough in advance (at least 3 months) to attract interesting speakers and motivate participants to attend.

$\checkmark \quad$ We need to be careful not to organise the event very near the public holidays as people tend to take few days more off.

$\checkmark \quad$ On the invitation we need to clearly state the purpose of the event and that replies from participants will be collected on selected topics.

$\checkmark$ There should be an appropriate number of participants to enable work in groups (not too small and not too many, between 20 and 60).

$\checkmark$ We shouldn't exaggerate with the number of presentations as participants will get tired and might even leave earlier.

$\checkmark$ We need to very carefully define what we would like to find out in the discussion or in group exercise. Competent and well prepared moderator (and/or facilitators) has a crucial role in leading to successful outcome of the discussion.

$\checkmark$ Coffee breaks and lunch break are an important opportunity for the participants representing different target groups to continue the discussions and mingle informally. 


\section{Techniques for Interactive Workshops}

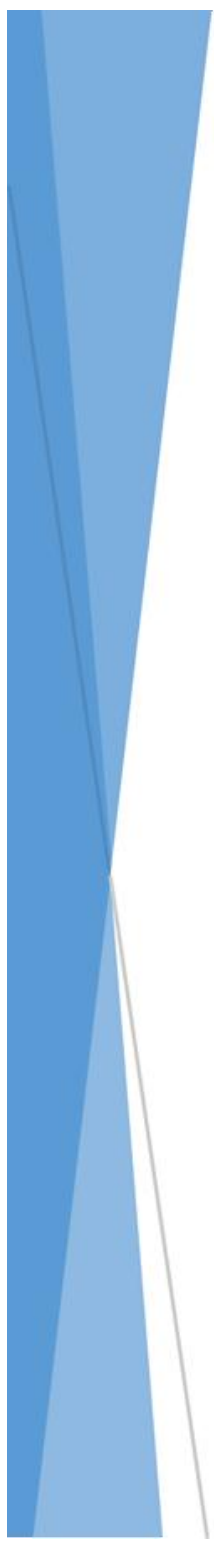

Discussing in smaller groups has numerous benefits. In this chapter some techniques used at interactive workshops are presented. There is in fact no recipe on how to choose the right techniques for running a workshop; this is the creative part of the whole process where we can play with our ideas to put together a series of actions that will lead us to our goals that we set for the event.

The key is to find the most appropriate techniques to achieve what we want in the time that we have available for single sessions.

At the SNAP-SEE events, the experience has proven that discussing in small groups of 7-10 persons has several benefits, e.g. more people participate in the discussion, there is more exchange of opinions and experience, and different solutions are identified and upgraded. 


\subsection{Before We Start}

At a consultation event, working in groups has numerous benefits and can lead to very inspiring results, which was also the case at the SNAP-SEE events. Several techniques can be used and have to be chosen based on our goals. We need to decide:

$\checkmark \quad$ Will we work in one group or in more groups;

$\checkmark$ Will every group work on the same issue/same question, or should each group have its own topic;

$\checkmark$ How to divide the participants into groups;

$\checkmark \quad$ Make a list of appropriate techniques and then compare them to the available time, space and available facilitators - on the basis of this you can decide on the one that seems the most appropriate; and

$\checkmark$ Decide on how the room shall be arranged for the interactive part of the event.

Additionally, we should decide on:

$\checkmark$ Materials we will need: flipcharts, pens etc.;

$\checkmark$ Materials that the facilitators will need;

$\checkmark$ Materials to be prepared for the participants and handed out to them; and

$\checkmark$ Distribution of roles of the organisation team at the event: who will be the main facilitator, who will be facilitators in groups, who will record what is being said, who will take care of practical arrangements.

\subsection{Dividing People into Groups}

Deciding to group people ourselves has the advantage that it disperses people from the same organizations or with similar interests. Groups formatted this way are much more "colourful" from the groups that are made by self selection as like-minded people will likely choose the same groups.

\section{Some ways to group people:}

$\checkmark \quad$ Numbering people off and then ask all the 'ones' to go to workspace one, 'twos' to workspace two and so on. People from the same organisations usually sit or stand together so in this way you will mix them up.

$\checkmark \quad$ Give people a random colour or shape as they register and divide them into groups using the same colours or shapes. This can be done by sticking a coloured dot on the name badges or by giving them name badges of different colours. Then you ask all participants with orange colour to go to one group, the "reds" to another and so on. 
$\checkmark \quad$ This is especially useful if you want to mix up different sectors. You give each sector one colour and then you can mix the groups by limiting the number of "greens", "blues" and so on.

$\checkmark \quad$ If it is not really important to you how you divide them you can simply divide them by taking the first 10 people sitting together into one group, the next 10 into another and so on.

\subsection{Carousel Brainstorming}

Carousel brainstorming is a useful method for generating a large number of responses to an issue in a short time. Its benefits are:

$\checkmark \quad$ The method enables exploring multiple perspectives of an issue.

$\checkmark \quad$ Moving around stations with different questions enables collecting different suggestions.

$\checkmark \quad$ Working in groups encourages more shy people to speak.

$\checkmark \quad$ It enables assessing the overall knowledge of a group of people about a particular issue.

$\checkmark \quad$ It's a physically active session so it will create energetic atmosphere.

Carousel can be used for up to 60 participants divided in 6 different groups of 10 people. Five steps for its implementation are summarized on the next page. 


\begin{tabular}{|c|c|}
\hline \multicolumn{2}{|c|}{$\begin{array}{l}\text { How to run the carousel brainstorming - used at the SNAP-SEE consultations to collect } \\
\text { opinion of stakeholders }\end{array}$} \\
\hline $\begin{array}{l}\text { 1. Decide on } \\
\text { the number } \\
\text { of groups }\end{array}$ & $\begin{array}{l}\text { - } 1 \text { group = } 1 \text { question. } \\
\text { - You can use the questions below or make new/additional ones, tailored } \\
\text { to the project topic. } \\
\text { - Up to } 6 \text { questions/groups are manageable with the carousel technique. }\end{array}$ \\
\hline $\begin{array}{l}\text { 2. Divide } \\
\text { participants } \\
\text { into groups }\end{array}$ & $\begin{array}{l}\text { - You can use methods listed in Chapter } 6.2 \text { for dividing people into } \\
\text { groups. }\end{array}$ \\
\hline $\begin{array}{l}\text { 3. Do the } \\
\text { carousel }\end{array}$ & $\begin{array}{l}\text { - The carousel works by rotating people around a number of 'stations'. } \\
\text { - } \quad \text { Arrange the stations around the room - one for each question. } \\
\text { - Each station has a different, but related, question or task. } \\
\text { - Each group has their own colour of marker. } \\
\text { - Each group starts at a different station and responds to that question, } \\
\text { listing their answers to the flipchart paper at the station. The facilitator } \\
\text { writes down all the replies, if possible without changing them. } \\
\text { - After a short time ( } 20 \text { minutes is maximum) ask the group to move to } \\
\text { the next station. They have to take their pen with them in order to mark } \\
\text { - each group's contribution in their own colour. } \\
\text { - When the groups arrive at the next station the facilitator shortly sum- } \\
\text { - The arriving group then adds their thoughts or comments. } \\
\text { - The amount of time at each station should decrease (e.g. } 20,15 \text { and } 10 \\
\text { - Thinutes). } \\
\text { - } \text { - The rotation should allow the group to get back to their home station to } \\
\text { - } 45-60 \text { minutes is usually enough time for three or four groups, up to } \\
1,5 \text { hour for up to six stations. } \\
\text { - At the end, the facilitators of each group can summarize the key find- } \\
\text { ings to the whole audience. }\end{array}$ \\
\hline $\begin{array}{l}\text { Materials } \\
\text { you will need }\end{array}$ & 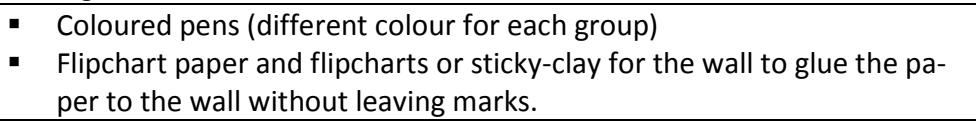 \\
\hline $\begin{array}{l}\text { How to rec- } \\
\text { ord the find- } \\
\text { ings }\end{array}$ & $\begin{array}{l}\text { - Take photos of the filled-in flipcharts and/or take them home with you. } \\
\text { - Use them to summarise the observations in the event report as an input } \\
\text { for your further work. }\end{array}$ \\
\hline
\end{tabular}




\subsection{World Café}

One of the varieties of the carousel is the so-called World café method. This is a simple method for encouraging conversation among participants about defined questions. The method allows for collecting ideas and experiences of each group member in a short period of time (1-2 hours). Main characteristics of this method are:

$\checkmark$ One table for one question, participants sit around each table.

$\checkmark$ Put on the table flipcharts and markers (each table has a different colour).

$\checkmark \quad$ We put snacks, biscuits and coffee on the table to make it resemble a café the method mimics a relaxed discussion at a café.

$\checkmark$ One person out of each group (or a facilitator) is nominated as "host of the table" and will stay at the table during the whole process.

$\checkmark$ After 20 minutes of discussion groups change the table.

$\checkmark$ Host of the table presents briefly the results of the previous group and then they can start editing their own answers.

$\checkmark$ You can choose to have the same question in all groups. In this case participants stay at the same table all the time and do not move around.

Using the interactive discussion methods at the SNAP-SEE events: both carousel and world café methods were used. Several different questions were asked, seeking the feedback of participants about the problems with aggregates planning in their country and the specific topics (e.g. how to integrate primary and secondary planning; how to make the quarrying more friendly to the nature; how to motivate local communities to accept quarrying etc.). Besides, we asked for possible solutions, steps towards these solutions, and organisations which should take care of them. Overall it was a very positive experience to use the interactive discussion methods since more people participated in the discussion and useful suggestions were shared. 


\section{Implementing the Event}

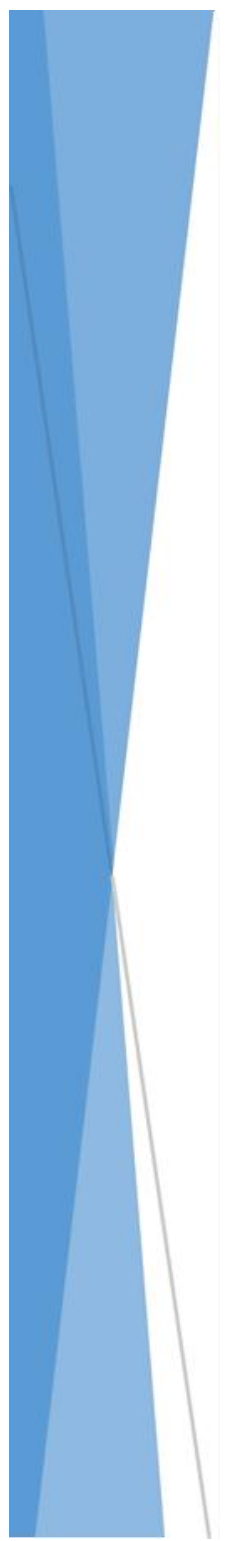

Key activities on the day when the event is implemented include briefing the team, setting up the room and practical arrangements, good facilitation and finishing the event so that the participants will leave with good impression.

On the day when the event will happen, we have to be sure that the detailed event plan we prepared will work and the day will run smoothly. This includes checking the event plan, briefing the team and ensuring all the practical arrangements are in hand.

One of the key experiences of the SNAP-SEE events is that you have to be flexible - for sure something will not go exactly according to the plan, but you should stay calm and adapt to the new circumstances, and the result will still be achieved. 


\subsection{Reviewing the Event and Briefing the Team}

Just before the start of the event run through the programme one more time with your team. Run through briefings and instructions for participants to ensure that they are written in the clearest language possible. Make sure everyone on the team knows what is expected of them.

\subsection{Setting up the Room}

Check if the room-layout has been arranged as required. How tables and chairs should be arranged in a meeting room depends on how the content will be delivered to participants. Choose a room that will help you achieve your objectives for your event. Room layout is usually left up to chance, but where and how people sit significantly influences the course of the event as shown in the table below.

\begin{tabular}{|c|c|c|}
\hline Theatre style & $\begin{array}{l}\text { Rows of chairs facing the front of the room, } \\
\text { usually divided by centre and/or side aisles. } \\
\text { Maximizes meeting room space utilization. } \\
\text { Theatre works well when the audience needs } \\
\text { to take minimal notes and/or the presenta- } \\
\text { tions are } 2 \text { hours or less in length. }\end{array}$ & $\begin{array}{l}\square \\
\square \square \square \square \text { 口 } \square \square \square \\
\square \square \square \square \\
\square \square \square \\
\square \square \square\end{array}$ \\
\hline $\begin{array}{l}\text { Classroom } \\
\text { style }\end{array}$ & $\begin{array}{l}\text { Rows of tables with } 2 \text { or } 3 \text { chairs at each table, } \\
\text { with tables arranged to face the front of the } \\
\text { room. Appropriate when the conference is an } \\
\text { informational type presentation. The present- } \\
\text { ers are providing the information, with some } \\
\text { dialogue with the audience. }\end{array}$ & \\
\hline $\begin{array}{l}\text { U-shaped } \\
\text { arrangement }\end{array}$ & $\begin{array}{l}\text { Promotes equality and interaction and allows } \\
\text { the presenter to move freely to the individual } \\
\text { group members and address individuals. This is } \\
\text { a good layout for discussions. }\end{array}$ & 跑吅吅 \\
\hline $\begin{array}{l}\text { Round table } \\
\text { arrangements }\end{array}$ & $\begin{array}{l}\text { Encourage contributions from all participants if } \\
\text { you plan to have discussion during the event. If } \\
\text { you are planning to have discussion with all } \\
\text { participants together then remove the table, } \\
\text { and put only chairs in a circle. If you are plan- } \\
\text { ning to implement the "world café" method } \\
\text { then prepare several smaller round tables as } \\
\text { seen on picture. }\end{array}$ & \\
\hline
\end{tabular}


Additionally, you need to arrange:

$\checkmark$ Registration: registration desk, badges with participants' names and materials for participants;

$\checkmark \quad$ Materials and equipment in the room: posters, presentations etc.; and

$\checkmark$ Refreshments with the catering providers.

\subsection{During the Event}

And at last - the room is set, the participants have arrived and now the event starts. You have done your preparations well so you are calm and relaxed at the beginning of the event. The success of the event now relies on: (a) good facilitation; (b) keeping to the times and topics of the agenda; and (c) carefully recording what is being said, taking into account all participants and all comments.

\subsection{Facilitation and Facilitators}

Running interactive workshops with many different interests requires a team of well prepared facilitators. Facilitation is one of the key skills for working with groups of people. The facilitator is very clear about what the group is there to do, but less structured about the way the group will achieve the outcomes. Skills of a good intervener - besides good verbal and non-verbal communication skills - are presented in the table.

\begin{tabular}{|l|l|}
\hline Listening & $\begin{array}{l}\text { Show that you are interested, both in what they are saying and why they are } \\
\text { saying it. This creates a trusting and supportive atmosphere. }\end{array}$ \\
\hline Questioning & $\begin{array}{l}\text { Ask the right questions, of the right people, at the right time, in the right way. } \\
\text { This will keep the discussion moving forward. }\end{array}$ \\
\hline Reframing & $\begin{array}{l}\text { Manage tension and negativity, focusing on shared goals. This skill is particu- } \\
\text { larly important when there is a lot of conflict or tension in the room. }\end{array}$ \\
\hline Cutting-off & $\begin{array}{l}\text { Be prepared to cut off talkative or aggressive panel members or those who } \\
\text { ramble off topic. Having some pre-planned cut-off phrases helps. E.g., if } \\
\text { someone goes off on a theme that is not useful to the overall topic, you could } \\
\text { interrupt and say, "You have an interesting point there, but we want to know } \\
\text { more about } \\
\text { watch the person's natural breathing rhythm and then interject between } \\
\text { breaths, "Thank you, Julie. Now let's hear Bob's perspective on this topic." }\end{array}$ \\
\hline
\end{tabular}

\section{Recording}

In small groups one person can be a facilitator and record everything that is said, but in bigger groups we advise to have two people, one for each task. Key to good recording is to provide concise record of dialogue, clear, easy to read and easy to fol- 
low. You have to capture the essence and write down everything that is said. Some additional advices for good recording:

$\checkmark \quad$ Listen and be precise - try to use their words;

$\checkmark \quad$ If unsure check with the participants that the wording is OK;

$\checkmark$ Don't worry too much about spelling;

$\checkmark$ When starting each line us a dash (-);

$\checkmark$ Put a number on each listed flipchart; and

$\checkmark$ Use big enough lower case letters.

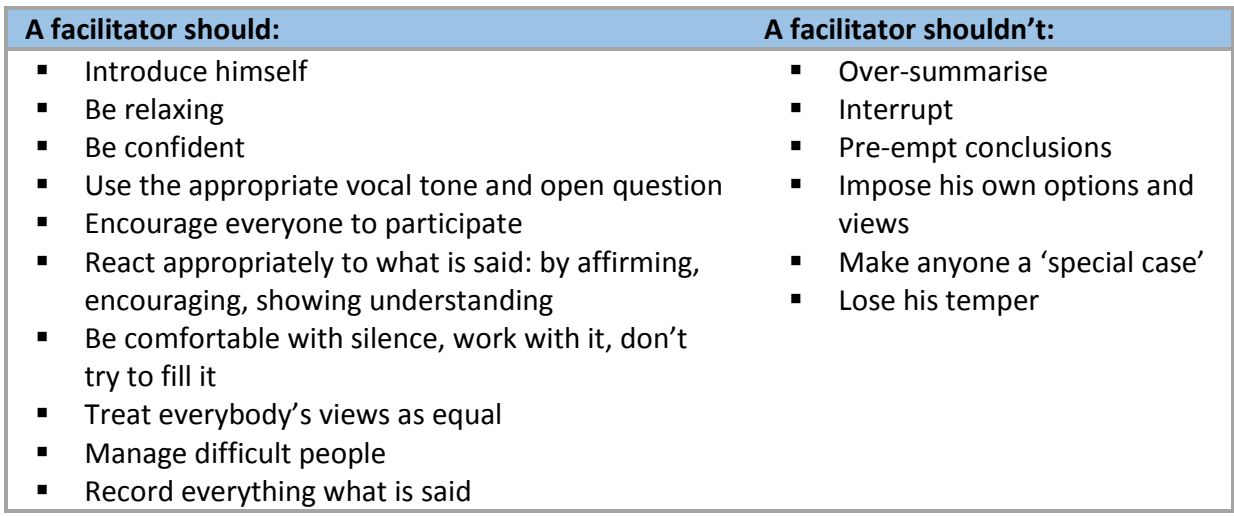

\subsection{Finishing the Event}

At the end of the event there will be some finishing up activities including making conclusions, explaining next steps in the process or where results from the workshop will be used, and getting feedbacks from participants. An evaluation questionnaire can be used for this purpose. It is distributed to all participants at the end of the event asking for their opinion on several issues: did the event meet their expectations, did they learn something new, did they have the opportunity to ask questions or give their views, was the event properly organised, do they have suggestions for making future events better etc.

\section{Finishing of the event:}

$\checkmark \quad$ Make the concluding words, answer any unanswered questions.

$\checkmark$ Clearly communicate how and where the results from the workshop will be used, what are the next steps and when will they happen.

$\checkmark$ Distribute evaluation questionnaires.

$\checkmark$ Closing words / thank you for coming.

$\checkmark$ Collect all questionnaires and materials.

$\checkmark \quad$ Clearing up work space. 


\section{After the Event - Follow-up}

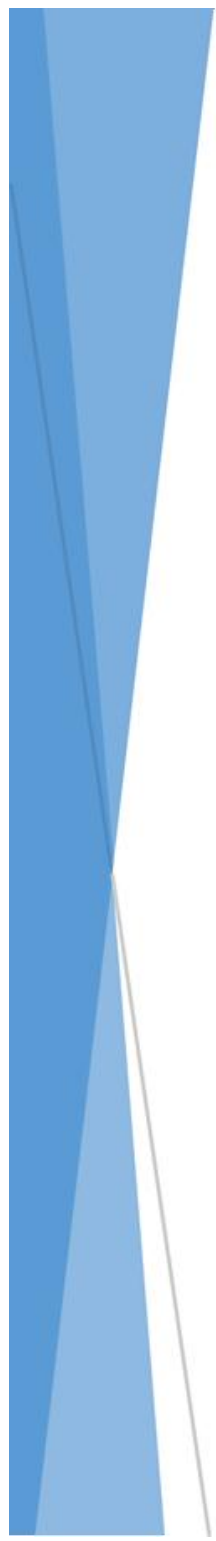

No matter how successful the event was and how satisfied the participants were, it can all easily go to waste very quickly if you do not ensure proper follow-up to the event. It is therefore important that you keep to the agreed deadlines to sending the promised materials and information. You should communicate with the participants in 1-2 weeks after the event.

In this chapter it is shortly summarized what you should send to the event participants, why, and how to start preparing for the next event or step in the process.

After the SNAP-SEE events, the participants received several handouts by e-mail: summary report of the event, recording of the (interactive) discussion, list of participants and the presentations. 


\section{What has to be sent to the event participants?}

You should send to the participants:

$\checkmark$ A short report of the event with transcripts of word-by-word recordings from the workshops - do not try to summarise, but leave it written in the words of the participants.

$\checkmark$ Explain how you will use the results of the workshop and their inputs.

$\checkmark$ Include also the evaluation results.

$\checkmark$ Attach presentations which were presented at the event, scanned attendance lists and photos.

$\checkmark \quad$ Inform them about the next steps or next events.

Why?

$\checkmark$ To show that you value their opinions and that you carefully recorded what they were saying.

$\checkmark$ To keep the participants involved and informed.

$\checkmark$ You need to let participants know what will happen to their views (which they shared during the workshop) if you want them to take part again. This will encourage all participants to feel that their views have been taken into account.

\section{After the event:}

$\checkmark$ Send report of the event/workshop to all participants (with presentations and photos) and those who were invited but couldn't participate.

$\checkmark$ Prepare a press release about the event for the media.

$\checkmark \quad$ Keep participants up-to-date and involved in others related events too.

When the event is finished, you should also evaluate it within your organisation and the coordination team, and put it in the perspective of the overall process:

$\checkmark$ Did we achieve the event purpose?

$\checkmark \quad$ Who were the participants? Did they represent the (key) stakeholder organisations?

$\checkmark$ Who was missing? Why? What can we do to attract them in the process?

$\checkmark \quad$ What will we do with the feedback?

$\checkmark$ Who will prepare the project report?

$\checkmark$ Do we need additional analyses, information etc.? Do we need to consult additional experts to find that out?

When we start thinking about the next event, we should reconsider all the steps taken and estimate how activities can be improved (where necessary) next time. 


\section{Conclusions and Recommendations}

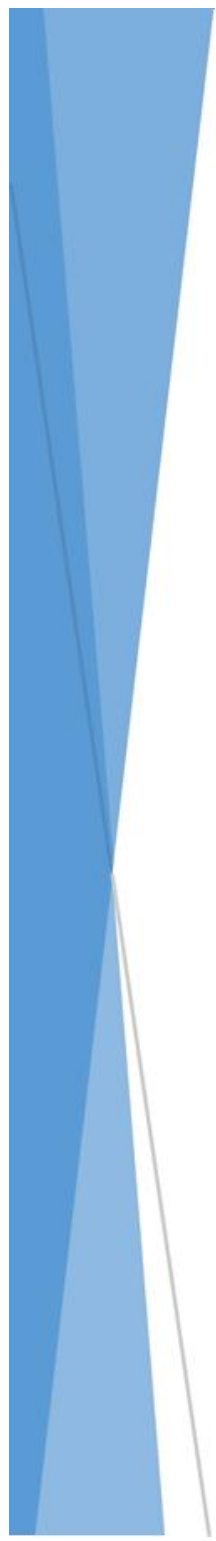

As a summary, recommendations are summarized for each of the chapters. They provide the key guidelines that need to be considered when planning a participatory process, implementing a single workshop or using one of the interactive techniques.

The recommendations are based on the experience of the SNAP-SEE project partners with the consultations they have held, of the handbook authors and literature review. We strongly recommend trying and using the proposed methods to find out their benefits and learn by doing. 
The purpose of the SNAP-SEE project was to increase capacity of stakeholders and develop tools for assuring sustainable supply of aggregates in the South East Europe. Twenty seven partners from 13 countries have analysed their current state of aggregates planning, developed guidance for enhancing the process and agreed about the Vision of Best Practices for Aggregates Planning in South East Europe.

One of the findings is that each country should develop their aggregates or minerals plan for the next 20 years. However, the planning is done by the governments and cannot be implemented solely by project partners. The Toolbox for Aggregates Planning is a result of project experience and presents supporting documents for any interested organisation facing such challenge. It is essential to involve the stakeholders in a participatory manner in the process as early as possible. At this point the key recommendations are summarized.

Benefits of consulting stakeholders in support of best practices in sustainable aggregates planning

$\checkmark \quad$ Involving stakeholders representing different opinions about the aggregates - governmental bodies, professionals, the industry, NGOs and local communities - enables collecting wider knowledge and experience and identifying better solutions. It is essential to listen to different options and consider views of several target groups if we want to achieve a win-win situation.

$\checkmark$ Running a participatory process might seem longer and costly at first, but overall it will result in better informed decision with a broader support.

$\checkmark$ Consultations are a good way for motivating the target groups to implement best practices in aggregates planning and consider opinions of others involved.

$\checkmark$ Agreements reached in a participatory manner are easier to implement.

$\checkmark$ Organising consultation events results in enhanced cooperation between different institutions in charge of or affected by aggregates planning.

$\checkmark \quad$ The results also include: increased awareness about the importance of planning, the need for preparing a national or regional minerals plan or policy, and promotion of use of secondary aggregates.

$\checkmark$ People are getting tired of just participating at useless events. If you invite them, be clear on the purpose and the added value they will bring and get. 


\section{Planning the participatory process with stakeholders}

$\checkmark$ We need to clearly define the purpose of the consultations, what we want to achieve, who should participate and how will we use the information collected.

$\checkmark$ Participants need to be informed about the purpose, their role and how they can influence the decisions.

$\checkmark$ The overall aim of the process was to achieve more sustainable supply of aggregates by involving all affected target groups.

$\checkmark$ The outcome can be: better understanding of aggregates planning process, agreement on solutions, increased capacity on SARM and SSM concepts, and good practices in other countries, increased awareness of sustainable approaches, and increased knowledge of up-to date data and methods.

$\checkmark$ Timing of the process and separate steps have to be carefully defined to achieve the overall aim.

\section{Who are the stakeholders and how to involve them}

$\checkmark$ Each consultation process has different target groups. We need to carefully define who the groups in charge of making decisions are, those being involved or influenced by the process.

$\checkmark \quad$ Key target groups in the aggregates planning are: governmental authorities of different sectors, aggregates industry, experts, local community and NGOs, and the general public and the media.

$\checkmark \quad$ Needs of different stakeholder groups differ and we have to consider this when planning types and extent of involvement. Some will gladly participate at one-day workshops while with others we will need to organise a short meeting to collect relevant information from them.

$\checkmark$ The interests of different target groups vary widely. Their opinions differ a lot and can be opposite to each other. Therefore we need to carefully consider how to cooperate with all of them and avoid escalating conflicts.

$\checkmark \quad$ Industry is very motivated to cooperate and we must be careful that they are equally represented. They are interested that the authorities assure stable and fair working conditions for their operations.

$\checkmark \quad$ Expert organisations and experts from different areas will provide important insights into different themes.

$\checkmark$ Representatives of the environmental sector, NGOs and communities are also interested to be included in the dialogue from the start so that their opinions can be considered. Experience shows that they are not a priori against (quarrying) operations but they are too often left behind to the last stage of the process. 


\section{Planning the event}

$\checkmark \quad$ The timing for planning the event implementation is crucial. For a single event start planning at least 6-8 weeks in advance. For an international event, you should start 6 months before the date.

$\checkmark$ Carefully select the date of the event, avoid busy periods, public holiday, school holidays or main sport events.

$\checkmark$ Choose the place for the event that is suitable to your needs: accessible, of suitable size for the planned number of participants and the agenda.

$\checkmark$ Define the head of the preparation team, team members and their roles. Regularly check the progress of allocated tasks.

$\checkmark$ Clearly define the purpose of each single event and how you plan to achieve it - is your aim informing participants and you need a number of presentations, do you need to collect a large number of ideas, or would you like to reach an agreement?

$\checkmark \quad$ The structure of the event has to be adapted to the above mentioned aims round table discussion, interactive work in groups, prioritising.

$\checkmark$ Based on the desired structure of the event you need to prepare the appropriate agenda.

$\checkmark$ Coffee breaks (and even lunch break) are important to enable informal gathering of participants and exchange of views.

\section{Techniques for interactive workshops}

$\checkmark \quad$ Work in groups has several benefits as it will allow more participants to get involved in the discussion and tell their opinions.

$\checkmark$ Techniques have to be chosen based on what we want to achieve - a number of ideas, in-depth discussion, prioritising.

$\checkmark$ Additional information can be found at: http://participationcompass.org/.

\section{Implementation of the event}

$\checkmark$ Review the tasks with the team before the start.

$\checkmark$ Be relaxed and positively oriented. Trust in achieving good results.

$\checkmark$ Set-up the room in line with the schedule, and to allow best possible participation of those who devoted their time to your event.

$\checkmark$ Well prepared and experienced facilitators are the key to success. 
Finishing the event and follow-up

$\checkmark \quad$ At the end of the event inform the participants of what will happen next.

$\checkmark$ Send to participants (and those who couldn't come) the thank you letter in 1-2 days, and the event report and materials in 1-2 weeks.

$\checkmark \quad$ Keep them informed about the overall process and the results.

$\checkmark \quad$ If you will carefully plan the process and the event, this will guarantee you successful implementation and satisfied participants. 


\section{References and Further Reading}

Århus Convention: UNECE Convention on Access to Information, Public Participation in Decision-making and Access to Justice in Environmental Matters. http://www.unece.org/env/pp/treatytext.html

British Geological Survey (2006). Planning4Minerals: A Guide on Aggregates. http://www.bgs.ac.uk/planning4minerals/assets/downloads/86210_P4M_A_Gui de_On_Aggregates.pdf

Chalkiopoulou, F. \& Hatzilazaridou, K. (2011). How to achieve aggregates resource efficiency in local communities, a joint manual, for stakeholders' decision making on the local level, SARMa (SARMa - SEE/A/151/2.4/X). http://www.sarmaproject.eu

Chreighton, J. L. (2005). The Public Participation Handbook: Making Better Decisions Through Citizen Involvement. John Wiley \& Sons, Inc.

Dolinar, U. \& Kozinc, Z. (2013). Stakeholder involvement as a key factor for sustainable aggregates planning and management, Proceedings, 6th International Conference on Sustainable Development in the Minerals Industry (SDIMI), Milos, Greece.

Erricsson, M. \& Särkkä, P. (2013). Socio-economic impact of the Finnish extractive industries. Proceedings, 1st International Conference on Sustainable Development in the Minerals Industry (SDIMI 2003), Milos, Greece, pp. 243-251.

Getzner, M. et al. (2010). People, parks and money. Stakeholder involvement and regional development: a manual for protected areas. Klagenfurt, Verlag Johannes Heyn.

Global Reporting Initiative (2002). Sustainability Reporting Guidelines.

International Council on Mining and Metals (2003). Community Development Toolkit. ICMM, London.

Korff, von Y. et al. (2010). Designing Participation Processes for Water Management and Beyond. Ecology and Society, vol. 15., No. 3. http://www.ecologyandsociety.org/vol15/iss3/art1/

Marega, M. (2011). Guidelines on Stakeholder Engagement in Preparation of Integrated Management Plans for Protected Areas. NATREG project. http://www.zrsvn.si/dokumenti/64/2/2010/Guidelines_on_stakeholder_engage ment_REC_1978.pdf 
MMSD (2002). Breaking new ground. Final report on the Mining, Minerals and Sustainable Development Project. IIED, London. http://pubs.iied.org/pdfs/9084IIED.pdf

New Zealand Planning Institute (2013). Quality planning New Zealand.

http://www.qualityplanning.org.nz/index.php

Nielsen, K. (2003). Sustainable development indicators in the aggregate industry. A Norwegian perspective. Proceedings, 1st International Conference on Sustainable Development in the Minerals Industry (SDIMI 2003), Milos, Greece, pp. 285289.

Participation compass (2013). participationcompass.org

Participation Directive (2003). Directive 2003/35/EC of the European Parliament and of the Council of 26 May 2003 providing for public participation in respect of the drawing up of certain plans and programmes relating to the environment and amending with regard to public participation and access to justice Council Directives 85/337/EEC and 96/61/EC.

Pound, D. (2008). Stakeholder dialogue, A good practice approach to participation. Dialogue Matters Ltd.

Softić, M., et al. (2011). Training Manual for Organisation of National Seminars within the DMCSEE project. DMCSEE (DMCSEE - SEE/A/091/2.2/X).

Šolar, V.S., Shields, D.J., \& Zelič, U. (2012). Sustainable Aggregates Resource Management: experience learnt and shared within South East Europe. Ljubljana: Mining and Metallurgy Quarterly (RMZ - Rudarsko metalurški zbornik).

Šolar, V.S. \& Shields, D.J. (2011). The SARMa Project: enhancing sustainable aggregates resource management and supply in Southeast Europe. In: Martens, P. (ed.) Proceedings, $5^{\text {th }}$ Conference on the Sustainable Development in the Mineral Industry (SDIMI 2011). June 14-17, Aachen, DE. Essen, DE: RWTH Aachen University.

The Environment Council (2004). Good Practice for Stakeholder Engagement in the Aggregates Sector. http://www.sustainableaggregates.com/library/docs/ samp/l0138_samp_1_019.pdf

Tiess, G. (2001). General and International Mineral Policy. Focus Europe, Springer.

Tiess, G. \& Chalkiopoulou, F. (2011). SARM and SSM at the Regional, National and Transnational Level manual, SARMa (SARMa - SEE/A/151/2.4/X).

Van der Veen, P. \& Strongman, J. (2003). Sustainable development - The way forward for the mining industry, Proceedings, 1st Int/nal Conference on Sustainable Development in the Minerals Industry (SDIMI 2003), Milos, Greece, pp. 17-23. 
64 


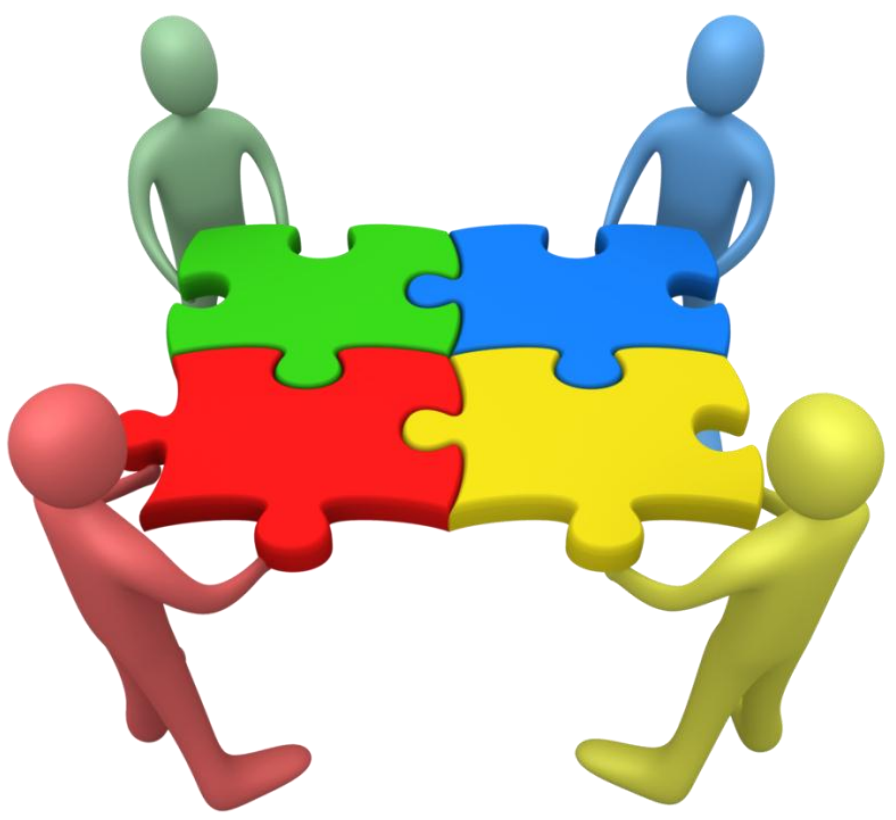

Sustainable Aggregates Planning in South East Europe (SNAP-SEE) 